\title{
Cidades inteligentes: principais rankings e propostas de melhoria para São Luís,
}

\section{Maranhão}

\author{
Smart cities: main rankings and improvement proposals for São Luís, Maranhão \\ Ciudades inteligentes: principales rankings y propuestas de mejora para São Luís, Maranhão
}

Recebido: 22/03/2021 | Revisado: 29/03/2021 | Aceito: 08/04/2021 | Publicado: 18/04/2021

\author{
Belisa Souza Costa \\ ORCID: https://orcid.org/0000-0003-1000-231X \\ Universidade Federal do Pará, Brasil \\ E-mail: belisasc@hotmail.com \\ Sueli de Souza Costa \\ ORCID: https://orcid.org/0000-0003-4127-7324 \\ Universidade Federal do Maranhão, Brasil \\ E-mail: scsueli@gmail.com \\ Nilson de Jesus Pereira Batalha Júnior \\ ORCID: https://orcid.org/0000-0002-6325-5655 \\ Universidade Federal do Maranhão, Brasil \\ E-mail: nilsonbatalha@gmail.com \\ Clauderino da Silva Batista \\ ORCID: https://orcid.org/000-0002-8506-4534 \\ Universidade Federal do Pará, Brasil \\ E-mail: clauderino@ufpa.br
}

\begin{abstract}
Resumo
O conceito de cidade inteligente (CI) se refere ao local adequado para as pessoas viverem, com recursos tecnológicos cooperando entre si, gerando bem-estar, inclusão social e participação de seus habitantes, além da sustentabilidade do meio ambiente, crescimento sustentável, monitoramento e integração de todos componentes de infraestrutura; manutenção preventiva, segurança, e serviços aos cidadãos. O presente estudo objetivou analisar os principais rankings que medem as condições das cidades e as classifica entre as CI, visando propostas de melhorias para a cidade de São Luís. Para isto, usa a cidade de Curitiba como referência nacional, primeiro lugar no Ranking Connected Smart Cities, enquanto São Luís não figurava entre as posições analisadas. Trata-se de uma pesquisa aplicada, qualiquantitativa, exploratória, sendo proposto um plano de intervenção, para tornar São Luís mais competitiva quanto à sua classificação como cidade inteligente e sustentável, nos itens mobilidade urbana, meio ambiente, saúde, tecnologia e inovação, e segurança. Tais itens foram consolidados em três linhas estratégicas para organizar as intervenções propostas: Gestão da administração pública; Gestão do saneamento básico, Adequação do uso do território e as relações entre o ambiente natural e o construído, bem como suas interferências sobre a mobilidade no município; além do tema transversal de gestão energética, aliado à aplicação de práticas sustentáveis e saneamento ambiental. Assim, é possível transformar São Luís numa cidade inteligente e sustentável, devendo haver investimentos, e parcerias para alcançar estas metas, melhorando a qualidade de vida de seus habitantes.
\end{abstract}

Palavras-chave: Cidades inteligentes; Planejamento urbano; Qualidade de vida.

\begin{abstract}
The concept of smart city (CI) refers to the appropriate place for people to live, with technological resources cooperating with each other, generating well-being, social inclusion and participation of its inhabitants, in addition to the sustainability of the environment, sustainable growth, monitoring and integration of all infrastructure components; preventive maintenance, security, and citizen services. The present study aimed to analyze the main rankings that measure the conditions of cities and classify them among ICs, aiming at improvement proposals for the city of São Luís. For this purpose, it uses the city of Curitiba as a national reference, first place in the Connected Smart Cities Ranking, while São Luís was not among the analyzed positions. It is an applied, qualitative and quantitative, exploratory research, and an intervention plan is proposed to make São Luís more competitive in terms of its classification as a smart and sustainable city, in terms of urban mobility, environment, health, technology and innovation, and security. These items were consolidated in three strategic lines to organize the proposed interventions: Management of public administration; Management of basic sanitation, Adequacy of the use of the territory and the relations between the natural and the built environment, as well as their interferences on mobility in the municipality; in addition to the transversal theme of energy management, combined with the application of sustainable practices and environmental sanitation. Thus, it is possible to transform São Luís into a smart and sustainable city, with investments and partnerships to achieve these goals, improving the quality of life of its inhabitants.
\end{abstract}


Keywords: Smart cities; Urban planning; Quality of life.

\section{Resumen}

El concepto de ciudad inteligente (CI) se refiere al lugar adecuado para que las personas vivan, con recursos tecnológicos cooperando entre sí, generando bienestar, inclusión social y participación de sus habitantes, además de la sostenibilidad del medio ambiente, crecimiento sostenible, seguimiento e integración de todos los componentes de la infraestructura; mantenimiento preventivo, seguridad y servicios al ciudadano. El presente estudio tuvo como objetivo analizar los principales rankings que miden las condiciones de las ciudades y clasificarlos entre los IC, con el objetivo de propuestas de mejora para la ciudad de São Luís. Para ello, utiliza la ciudad de Curitiba como referencia nacional, primer lugar en Connected Smart Cities Ranking, mientras que São Luís no se encontraba entre las posiciones analizadas. Se trata de uma investigación exploratoria aplicada, cualitativa y cuantitativa, y se propone un plan de intervención para hacer a São Luís más competitiva en términos de su clasificación como ciudad inteligente y sostenible, en términos de movilidad urbana, medio ambiente, salud, tecnología e innovación, y seguridad. Estos ítems se consolidaron en tres líneas estratégicas para organizar las intervenciones propuestas: Gestión de la administración pública; Gestión del saneamiento básico, Adecuación del uso del territorio y las relaciones entre el medio natural y construido, así como sus interferencias en la movilidad en el municipio; además del tema transversal de gestión energética, combinado con la aplicación de prácticas sostenibles y saneamiento ambiental. Así, es posible transformar São Luís en una ciudad inteligente y sostenible, con inversiones y alianzas para alcanzar estos objetivos, mejorando la calidad de vida de sus habitantes.

Palabras clave: Smart cities; Planificación urbana; Calidad de vida.

\section{Introdução}

No século XXI, o conceito de cidade inteligente (CI) passou a ser difundido como um local adequado para as pessoas viverem, onde há o monitoramento e integração de todos os componentes de infraestrutura, incluindo ruas, pontes, túneis, meios de transporte, edificações, sistemas de comunicação, redes de abastecimento de água e energia, entre outros; cabendo aos governos a otimização de recursos, a manutenção preventiva, garantindo segurança, enquanto maximizam seus serviços para os cidadãos (Hall, Bowerman, Braverman, Taylor, Todosow, \& Von Wimmersperg, 2000; Alves, 2018). Entretanto, o desenvolvimento urbano ordenado é apontado como grande desafio para a administração pública, considerando a busca da sociedade pela melhor qualidade de vida nas cidades (Mendonça, Morais, \& Silva, 2020).

Do ponto de vista do desenvolvimento e planejamento urbano, atualmente as CI estão sendo vistas como o paradigma dominante, conectando ambientes urbanos, de inovação e digitais e pondo em marcha poderosos motores sociotecnológicos para a mudança e crescimento sustentável (Komninos, 2015; Benites, 2016; Martins, Salles, de Macedo, Nunes, \& Ribeiro, 2020).

Nas cidades inteligentes há uma fusão de ideias sobre como a tecnologia da informação e comunicação podem melhorar seu funcionamento, aprimorando a eficiência, a competitividade e provendo novas formas de tratar problemas relacionados à pobreza, privação social e meio ambiente (Harrison et al., 2010).

Usando a tecnologia, as cidades podem se modernizar em benefício da população, surgindo como importante aliada aos problemas referentes à mobilidade urbana, bem como em outras áreas, como para gerar bem-estar, inclusão social e participação de seus habitantes, além da sustentabilidade do meio ambiente (Damieri \& Cocchia, 2013; Andrade \& Galvão, 2016; Berrone et al., 2019).

Estas cidades devem desenvolver as infraestruturas convencionais, como transporte, moradia, acesso à saúde, aliadas às estruturas modernas, através do uso de tecnologias, visando a melhora da qualidade de vida e geração de crescimento econômico sustentável, ao mesmo tempo em que realizam investimentos em capital humano e social (Caragliu, Del Bo, Nijkamp, 2011; Faria, Amaral Russi, Marcato, Paschoalin Filho, 2017). Para Kobayashi, Kniess, Serra, Ferraz e Ruiz (2017), as cidades inteligentes devem, ao mesmo tempo proporcionar qualidade de vida e serem sustentáveis, ao passo que as cidades sustentáveis seriam parte das inteligentes, devendo serem capazes de monitorar o fluxo de recursos através de tecnologias de informação e comunicação. 
O conceito de cidades inteligentes e sustentáveis (CIS) estaria relacionado àquelas cidades consideradas inovadoras, na medida em que utilizariam "tecnologias de informação e comunicação (TIC) e outros meios para melhorar a qualidade de vida, a eficiência de operações e serviços urbanos e a competitividade", bem como garantiriam o atendimento das necessidades das populações atuais e posteriores no que tange aos fatores culturais, sociais, econômicos e ambientais, de acordo com a International Telecommunication Union - ITU-T Study Group 5 - Focus Group on Smart Sustainable Cities (ITU, 2015; Höjer \& Wangel, 2015).

As CIS devem ter outros componentes, como o investimento social, o capital humano, comunicações, infraestrutura, assegurando a sinergia entre cada um dos elementos que o compõem, fazendo parte do modelo que se encontra em crescimento em várias partes do mundo devendo conter ainda investimentos inteligentes em economia, mobilidade, meio ambiente, recursos humanos e estilos de vida inteligentes (C40 SÃO PAULO CLIMATE SUMMIT, 2011; Duran \& Perez, 2015; Berrone et al., 2019, Martins et al., 2020).

Dado o reconhecimento dos problemas relacionados ao meio ambiente, mobilidade e segurança pública em grandes cidades, que interferem nos determinantes sociais de saúde, prejudicam a qualidade de vida das pessoas, e geram custos desnecessários para a sociedade, faz-se necessário o estudo de novas formas que viabilizem soluções imediatas para problemas incompatíveis com cidades inteligentes. São Luís - MA é uma capital brasileira que ainda não se encontra no rol de "cidades inteligentes", sofrendo com engarrafamentos no trânsito, dificuldades de acesso à saúde, problemas de abastecimento de água e coleta de esgoto, entre outros que já foram solucionados em locais que hoje são considerados "cidades inteligentes", sendo possível, desta forma, melhorar a qualidade de vida e do meio ambiente local.

É possível, através do uso de TIC's, solucionar problemas de engarrafamento no trânsito, melhorar o acesso aos serviços de saúde, proporcionar melhora da qualidade de vida e do meio ambiente através do planejamento urbano adequado. Este trabalho, fruto de dissertação de mestrado defendida na Universidade Federal do Pará, visa propor uma solução inteligente para a sustentabilidade urbana da cidade de São Luís-MA, com enfoque nos subitens utilizados para mensurar cidades inteligentes, especialmente mobilidade urbana, meio ambiente, saúde, tecnologia e inovação, e segurança. Ao traçarmos um projeto como o nosso, além de ir ao encontro do que reza a Constituição Federal como direito do cidadão, este pode ser um modelo a ser aplicado em outros locais, servindo de exemplo para a solução de problemas referentes às políticas públicas.

\section{Revisão da Literatura}

Nesta revisão de literatura são apontadas as definições de cidades inteligentes, e os principais rankings internacionais; as características da cidade de Curitiba, que foi utilizada como parâmetro para o plano de intervenção; como é possível migrar de uma cidade tradicional para uma cidade inteligente; a comparação Curitiba-São Luís, e a São Luís atual.

\subsection{Definições de cidades inteligentes}

Cada cidade possui sua particularidade, e com base nisso se determinam os indicadores a serem trabalhados. As cidades inteligentes possuem três dimensões: Ligadas a criatividade, inventividade e inteligência das pessoas residentes; relacionadas à inteligência coletiva, e, por fim, as que dizem respeito à inteligência artificial (Komninos, 2006; Komninos, 2008).

Segundo Komninos (2015), a contribuição das cidades para a economia global liderada pela inovação está ligada ao seu poder de criar sinergias entre tecnologias, conhecimento e habilidades espalhadas por populações e organizações. Tais cidades estariam ligadas a aspectos como: 
i. criatividade, inventividade e inteligência das pessoas: estas cidades, detêm o poder de atrair profissionais de moda, design, publicidade, entre outros relacionados as artes, com a capacidade criativa concentrada em 3 Ts: Talento, Tolerância e Tecnologia (Florida, 2002);

ii. inteligência coletiva, através de trocas de conhecimentos e valores entre os indivíduos, com a capacidade de decisão do próprio futuro, e a capacidade das comunidades criarem, inovarem e inventarem soluções para contribuir no dia a dia (Atlee, 2004);

iii. inteligência artificial, ou seja, programada por seres humanos para que máquinas e/ou softwares realizem determinada função de forma rápida e eficiente. É o exemplo de caso da cidade de Barcelona, que possui um sistema de tubulação subterrâneo a vácuo que transporta o lixo até uma central, evitando a chance de enchentes devido ao descarte incorreto de dejetos, que poderiam causar obstrução de bueiros das vias públicas (Lazaretti, 2012).

Para o Banco Interamericano de Desenvolvimento (BID), cidades inteligentes são aquelas em que as pessoas estão no centro do desenvolvimento, devendo haver incorporação de tecnologias da informação e comunicação na gestão urbana e utilização destes elementos para estimular a formação de um governo eficiente, englobando o planejamento colaborativo e a participação cidadã, a fim de estabelecer uma visão de longo prazo (Bouskela et al., 2016).

Para tornar as cidades mais inteligentes há a necessidade da combinação de planos estratégicos e recursos eletrônicos como parte de uma boa gestão de projetos (IPMA, 2019), considerando-se que em 2050 há a estimativa de que o mundo terá quase 10 bilhões de pessoas, das quais aproximadamente 64,1\% viverão nas cidades dos países em desenvolvimento (Bouskela et al., 2016).

Segundo Bouskela et al. (2016), três problemas básicos devem ser solucionados a curto prazo, sendo eles a sustentabilidade meio ambiental e a mudança climática, a sustentabilidade urbana, e a sustentabilidade fiscal e governança.

Ao estudar as cidades inteligentes, do ponto de vista da governança, Leydesdorff e Deakin (2011) destacam três desafios a serem enfrentados, incluindo o ranking de cidades inteligentes, os desenvolvimentos futuros da Internet e o que chamou de Triple Helix utilizada nas CIs, que contaria com o apoio da sociedade civil para o desenvolvimento cultural e ambiental de seus sistemas de inovação.

Quanto à sustentabilidade ambiental e mudança climática relacionadas à gestão de inovação, destaca a plataforma do Centro de Operações do Rio de Janeiro (COR), já que este figura como um caso de sucesso internacionalmente reconhecido desta nova tendência mercado-tecnológica e, portanto, um potencial agente difusor de lições aprendidas aplicáveis ao cenário de outros centros urbanos (Benites, 2016).

E, não apenas em relação à sustentabilidade urbana, é possível encontrar 50 exemplos de cidades inteligentes na publicação do BID no mundo (Iniciativa Cidades Emergentes e Sustentáveis - ICES, 2016), entre as quais são citadas sete brasileiras (Florianópolis, Goiânia, João Pessoa, Niterói, Palmas, Rio de Janeiro e Vitória), incluindo estudos de caso, desenhos de projetos, experiências e estratégias adotadas pela instituição em cidades da América Latina e Caribe (Bouskela et al., 2016).

O Ranking Connected Smart Cities, elaborado pela Urban Systems (2018), apenas com dados da região brasileira, aponta como cidades mais inteligentes e conectadas do Brasil as capitais São Paulo, Curitiba, Rio de Janeiro, Belo Horizonte e Vitória, na lista divulgada em 2017 (Calegari, 2017). Esta posição, do mesmo avaliador, modificou-se em 2018, com a entrada de Florianópolis e Porto Alegre entre as capitais consideradas inteligentes (Urban Systems, 2018).

Este ranking, avalia a integração entre mobilidade, urbanismo, meio ambiente, energia, tecnologia e inovação, economia, educação, saúde, segurança, empreendedorismo e governança em mais de 500 cidades brasileiras, usando 70 indicadores, distribuídos em 11 eixos temáticos, sendo eles: meio ambiente, energia, segurança, urbanismo, mobilidade, empreendedorismo, economia, educação, urbanismo, saúde, governança (Calegari, 2017). 
Com o uso destes indicadores, foi criado o Ranking Connect Smart Cities e apontadas as 100 cidades inteligentes, e o Ranking setoriais, com as 50 mais bem colocadas. Por estes indicadores, as posições referentes a 2017 e 2018 são as que se encontram no Quadro1, notando-se que, por ser um ranking colaborativo e dinâmico, pode haver alteração de posição das cidades a cada avaliação (Urban Systems, 2018).

Quadro 1. Classificação de cidades.

\begin{tabular}{|c|c|c|c|}
\hline \multicolumn{2}{|c|}{ Posição } & Município (UF) & Pontos \\
\cline { 1 - 2 } 2018 & 2017 & Curitiba (PR) & 31,782 \\
\hline $1^{\circ}$ & $2^{\circ}$ & São Paulo (SP) & 31,459 \\
\hline $2^{\circ}$ & $1^{\circ}$ & Vitória (ES) & 31,219 \\
\hline $3^{\circ}$ & $5^{\circ}$ & Campinas (SP) & 30,920 \\
\hline $4^{\circ}$ & $8^{\circ}$ & Florianópolis (SC) & 30,881 \\
\hline $5^{\circ}$ & $6^{\circ}$ & Rio de Janeiro (RJ) & 30,505 \\
\hline $6^{\circ}$ & $3^{\circ}$ & Belo Horizonte (MG) & 30,069 \\
\hline $7^{\circ}$ & $4^{\circ}$ & Porto Alegre (RS) & 29,991 \\
\hline $8^{\circ}$ & $11^{\circ}$ & Santos (SP) & 29,954 \\
\hline $9^{\circ}$ & $12^{\circ}$ & Niterói (RJ) & 29,884 \\
\hline $10^{\circ}$ & $18^{\circ}$ & Son & \\
\hline
\end{tabular}

Fonte: Urban Systems (2018).

Guimarães e Xavier (2016), ainda incluem, além do Rio de Janeiro, as cidades de Curitiba, Porto Alegre e São Paulo.

Cunha (2016), destaca um comparativo entre Porto Alegre e Curitiba, quanto à mobilidade urbana sustentável.

Censi (2016), aborda o gargalo de alguns pontos quanto às questões da cidadania, sustentabilidade e gestão no contexto da região metropolitana de Curitiba. Dullius et al. (2019), enfoca a sustentabilidade urbana no transporte público da referida capital. Weiss et al. (2013a) destacam que Curitiba é uma das 10 cidades mais inteligentes do mundo.

\subsubsection{Análises internacionais}

Os principais índices internacionais que indicam quais as cidades mais inteligentes do mundo são possíveis de serem verificados no Quadro 2, onde cidades podem estar em primeiro lugar num índice e em outra posição nos demais. Entretanto, cada índice utiliza indicadores diferentes (Berrone et al., 2019). 
Quadro 2. Comparação das 10 primeiras colocadas no ranking, dos principais índices internacionais de análise de cidades inteligentes.

\begin{tabular}{|c|c|c|c|c|c|c|c|}
\hline $\begin{array}{l}\text { Ran-king } \\
\text { by city }\end{array}$ & $\begin{array}{l}\text { CIMI } 2018 \\
\text { (IESE) }\end{array}$ & $\begin{array}{c}\text { Global Cities } \\
\text { Index } 2018 \\
\text { (A.T. } \\
\text { Kearney) }\end{array}$ & $\begin{array}{c}\text { Global } \\
\text { Finan-cial } \\
\text { Centres } \\
\text { Index } \\
\text { (GFCI) } \\
2018 \\
\text { (Z/Yen) } \\
\end{array}$ & $\begin{array}{c}\text { Global } \\
\text { Power City } \\
\text { Index 2018 } \\
\text { (MMF) }\end{array}$ & $\begin{array}{c}\text { Quality of } \\
\text { Living City } \\
\text { Ranking 2018 } \\
\text { (Mercer) }\end{array}$ & $\begin{array}{c}\text { Global } \\
\text { Liveability } \\
\text { Index } 2018 \\
\text { (Economist } \\
\text { Intelligence } \\
\text { Unit) }\end{array}$ & $\begin{array}{c}\text { Sustaina- } \\
\text { ble Cities } \\
\text { Index } \\
2018 \\
\text { (Arcadis) }\end{array}$ \\
\hline 1 & London & New York & London & London & Vienna & Vienna & London \\
\hline 2 & New York & London & New York & New York & Zurich & Melbourne & Stockholm \\
\hline 3 & Amsterdam & Paris & $\begin{array}{l}\text { Hong } \\
\text { Kong }\end{array}$ & Tokyo & Munich & Osaka & Edimburgh \\
\hline 4 & Paris & Tokyo & Singapore & Paris & Auckland & Calgary & Singapore \\
\hline 5 & Reykjavik & Hong Kong & Tokyo & Singapore & Vancouver & Sydney & Vienna \\
\hline 6 & Tokyo & Los Angeles & Shangai & Amsterdam & Dusseldorf & Vancouver & Zurich \\
\hline 7 & Singapore & Singapore & Toronto & Seoul & Frankfurt & Toronto & Munich \\
\hline 8 & Copenhagen & Chicago & $\begin{array}{l}\text { San } \\
\text { Francisco }\end{array}$ & Berlin & Geneva & Tokyo & Oslo \\
\hline 9 & Berlin & Beijing & Sydney & Hong Kong & Copenhagem & Copenhagen & $\begin{array}{l}\text { Hong } \\
\text { Kong }\end{array}$ \\
\hline 10 & Vienna & Brussels & Boston & Sydney & Basel & Adelaide & Frankfurt \\
\hline
\end{tabular}

Fonte: Berrone et al., (2019)

Para o ranking IESE Cities in Motion Index, 2017 (CIMI), do Center for Globalization and Strategy, da Business School University of Navarra (Berrone et al., 2019), a cidade de Nova York seria a mais inteligente do mundo naquele ano, enquanto que Curitiba apareceria em sétimo lugar (Nóbrega Jr, 2018).

Com uma população de 1,8 milhão de habitantes e uma rede de cerca de 30 parques e áreas florestais, que incluem macrodrenagem da cidade, onde cerca de $70 \%$ dos resíduos produzidos pela população é reciclado, Curitiba possui, entre outras características que a tornam inteligente, transporte urbano rápido e eficiente, sendo utilizado por $70 \%$ da população (Nóbrega Jr, 2018).

Lançado em 2019, o índice da University of Navarra CIMI 2018 aponta que Londres é a cidade mais inteligente do planeta, seguido de Nova York e em terceiro lugar Amsterdã, Curitiba ocupa o 140 lugar (Berrone et al., 2019).

Das cidades brasileiras, além de Curitiba, o ranking insere Rio de Janeiro (128 lugar), Brasília (130 posição), São Paulo (132 lugar), Salvador (146 lugar) e Belo Horizonte (151 a posição), O CIMI 2018 traz a análise de 174 cidades de todo o planeta, sendo que é possível fazer a consulta diretamente via internet (Berrone et al., 2019).

O IESE Cities in Motion Index (CIMI) 2018, é um índice que analisa o nível de desenvolvimento das cidades do ponto de vista de nove dimensões fundamentais: capital humano, coesão social, economia, meio ambiente, governança, planejamento urbano, alcance internacional, tecnologia e mobilidade/transporte, em diversas variáveis, incluindo o salário médio por hora, o poder de compra, hipotecas (como uma porcentagem da renda) e se as mulheres estão ou não habilitadas (Berrone et al., 2019).

A análise realizada com dados apenas do Brasil, considera onze dimensões para a análise de cidade inteligente, entre as quais energia, segurança, urbanismo, empreendedorismo, educação, urbanismo e saúde, além de alguns que também se encontram no IESE: meio ambiente, mobilidade, economia, e governança (Urban Systems, 2018).

O Global Cities Index 2018 (GCI), da A.T. Kearney, examina o desempenho e competitividade das cidades quanto a cinco aspectos: atividade comercial, capital humano, intercâmbio de informações, experiência cultural e governabilidade. Na 
Quadro3, é possível verificar quais os itens de cada aspecto são analisados, bem como a posição das cidades em 2018 (Hales et al., 2018).

Quadro 3. Ranking das cidades no Global Cities Index 2018 e seus aspectos.

\begin{tabular}{|c|c|c|c|c|}
\hline Business Activity & Human Capital & $\begin{array}{l}\text { Information } \\
\text { Exchange }\end{array}$ & Cultural Experience & Political Engagement \\
\hline New York & New York & Paris & London & Washington,D.C. \\
\hline \multicolumn{5}{|c|}{ Global Cities Index Leaders by Metric } \\
\hline $\begin{array}{l}\text { Fortune } 500 \\
\text { Beijing }\end{array}$ & $\begin{array}{l}\text { Foreign-born } \\
\text { population } \\
\text { New Tork } \\
\end{array}$ & $\begin{array}{l}\text { Acess to TV News } \\
\text { Geneva, Brussels }\end{array}$ & $\begin{array}{l}\text { Museums } \\
\text { Moscow }\end{array}$ & $\begin{array}{l}\text { Embassies and } \\
\text { consulates } \\
\text { Brussels } \\
\end{array}$ \\
\hline $\begin{array}{l}\text { Top Global Services } \\
\text { Firms } \\
\text { Hong Kong }\end{array}$ & $\begin{array}{l}\text { Top Universities } \\
\text { Boston }\end{array}$ & $\begin{array}{l}\text { New Agency Bureaus } \\
\text { London }\end{array}$ & $\begin{array}{l}\text { Visual and } \\
\text { performing arts } \\
\text { New York* }\end{array}$ & $\begin{array}{l}\text { Think tanks } \\
\text { Washingyon, D.C. }\end{array}$ \\
\hline $\begin{array}{l}\text { Capital Markets } \\
\text { New York }\end{array}$ & $\begin{array}{l}\text { Population with } \\
\text { Tertiary Degress } \\
\text { Tokyo }\end{array}$ & $\begin{array}{l}\text { Broadband } \\
\text { Subscribers } \\
\text { Geneva, Zurich }\end{array}$ & $\begin{array}{l}\text { Sporting events } \\
\text { London }\end{array}$ & $\begin{array}{l}\text { Internacional } \\
\text { organizations } \\
\text { Geneva }\end{array}$ \\
\hline $\begin{array}{l}\text { Air Freight } \\
\text { Hong Kong }\end{array}$ & $\begin{array}{l}\text { Internacional } \\
\text { Student Population } \\
\text { Melbourne* }\end{array}$ & $\begin{array}{l}\text { Freedom of } \\
\text { expression } \\
\text { Brussels, Amsterdam, } \\
\text { Stockholm }\end{array}$ & $\begin{array}{l}\text { Internacional } \\
\text { travelers } \\
\text { London }\end{array}$ & $\begin{array}{l}\text { Political conferences } \\
\text { Brussels }\end{array}$ \\
\hline $\begin{array}{l}\text { Sea Freight } \\
\text { Shangai }\end{array}$ & $\begin{array}{l}\text { Number of } \\
\text { International schools } \\
\text { Hong Kong }\end{array}$ & $\begin{array}{l}\text { Online Presence } \\
\text { Singapore }\end{array}$ & $\begin{array}{l}\text { Culinary offerings } \\
\text { New York }\end{array}$ & $\begin{array}{l}\text { Local institutions } \\
\text { with global reach } \\
\text { New York }\end{array}$ \\
\hline $\begin{array}{l}\text { ICCA Conferences } \\
\text { Paris }\end{array}$ & & & $\begin{array}{l}\text { Sisters Cities } \\
\text { St. Petersburg }\end{array}$ & \\
\hline
\end{tabular}

Fonte: Hales et al. (2018).

A A.T. Kearney também trabalha com outro índice, o Ranking Global Cities Outlook (RGCO), onde são mensurados quatro itens: bem-estar social, economia, inovação e governabilidade, com seus subitens (Quadro 4) (Hales et al., 2018).

Quadro 4. Ranking Global Cities Outlook 2018 e seus aspectos.

\begin{tabular}{|l|l|l|l|}
\hline Personal well-being & Economics & Innovation & Governance \\
\hline Melbourne & New York & San Francisco & Geneva, Zurich \\
\hline Global Cities Outlook leaders by metric & \multicolumn{2}{|l|}{} \\
\hline $\begin{array}{l}\text { Stabillity and security } \\
\text { Kuwait City }\end{array}$ & $\begin{array}{l}\text { Infrastructure } \\
\text { Frankfurt* }\end{array}$ & $\begin{array}{l}\text { Patents per capita } \\
\text { San Francisco }\end{array}$ & $\begin{array}{l}\text { Quality of bureaucracy } \\
\text { Multiple leaders }\end{array}$ \\
\hline $\begin{array}{l}\text { Healthcare Evolution } \\
\text { Multiple leaders }\end{array}$ & $\begin{array}{l}\text { GDP per capita } \\
\text { Houston }\end{array}$ & $\begin{array}{l}\text { Private investments } \\
\text { London* }\end{array}$ & $\begin{array}{l}\text { Ease of doing business } \\
\text { Moscow* }\end{array}$ \\
\hline $\begin{array}{l}\text { Gini coefficient index } \\
\text { Prague }\end{array}$ & $\begin{array}{l}\text { FDI inflow } \\
\text { New York* }\end{array}$ & $\begin{array}{l}\text { University-sponsored } \\
\text { Moscow }\end{array}$ & $\begin{array}{l}\text { Transparency } \\
\text { London }\end{array}$ \\
\hline $\begin{array}{l}\text { Environmental } \\
\text { performance } \\
\text { Sydney, Melbourne }\end{array}$ & & & \\
\hline
\end{tabular}

Fonte: Hales et al. (2018).

Ao combinar ambos índices, a A.T. Kearney produz o Ranking The Global Elite, que avalia as cidades mais influentes e atraentes do mundo, especialmente na área de negócios, reunindo informações sobre força relativa das economias locais, regionais e globais e suas políticas, cultura, desempenho econômico e investimento em infraestrutura correspondente. Este índice aponta a classificação das cidades, mas não suas dimensões analisadas (ver Quadro 5). Para a instituição, seriam 
necessárias 15 cidades para produzir a "cidade perfeita" em todas as 27 métricas do índice, cuja pontuação máxima é 100, sendo tal façanha ainda não encontrada na vida real (Hales et al., 2018).

Quadro 5. Cidades classificadas no Ranking The Global Elite 2018.

\begin{tabular}{|l|l|l|}
\hline AMERICAS & EMEA & ASIA PACIFIC \\
\hline New York, Index 1/Outlook 2 & London, Index 2/Outlook 3 & Tokyo, Index 4/Outlook 14 \\
\hline Chicago, Index 8/Outlook 15 & Paris, Index 3/Outlook 4 & Singapore, Index 7/Outlook 5 \\
\hline $\begin{array}{l}\text { Washington, D.C., Index 11/Outlook } \\
24\end{array}$ & Brussels, Index 10/Outlook 22 & Sydney, Index 15/Outlook 19 \\
\hline Toronto, Index 18/Outlook 12 & Moscow, Index 14/Outlook 20 & Melbourne, Index 17/Outlook 10 \\
\hline San Francisco, Index 20/Outlook 1 & Berlin, Index 16/Outlook 18 & Top 10 in both the Index and \\
\hline Boston, Index 24/ Outlook 8 & Vienna, Index 21/Outlook 25 & $\begin{array}{l}\square \text { Tutlook } \\
\text { Top 25 in both the Index and } \\
\text { Outlook }\end{array}$ \\
\hline & Amsterdam, Index 22/Outlook 6 \\
\hline
\end{tabular}

Fonte: Hales et al. (2018).

O Global Financial Centers Index (GFCI) realiza comparação sobre a competitividade dos principais centros financeiros do mundo. O GFCI 25, da Z / Yen Partners em colaboração com o China Development Institute, foi publicado em março de 2019, e a instituição divulga dois relatórios por ano que mapeiam o progresso dos principais centros financeiros do mundo (Yeandle \& Wardle, 2019). O GFCI utiliza 133 fatores em sua mensuração, incluindo a competitividade da infraestrutura de telecomunicações de um centro financeiro, que são extraídas do Índice de Desenvolvimento de TIC (fornecido pelas Nações Unidas), o Índice de Preparação de Rede (fornecido pelo Fórum Econômico Mundial), o Índice de Infraestrutura de Telecomunicações (pela Organização das Nações Unidas) e o Índice da Web (fornecido pela World Wide Web Foundation) (Yeandle \& Wardle, 2019).

As evidências sobre um ambiente regulatório favorável às empresas são extraídas do Índice Facilidade de Fazer Negócios (fornecido pelo Banco Mundial), do rating Eficácia do Governo (fornecido pelo Banco Mundial) e do Índice de Percepção de Corrupção (fornecido pela Transparency International), entre outros (Yeandle \& Wardle, 2019).

O Global Power City Index (GPCI), da Mori Memorial Foundation, utiliza índices para avaliar e classificar as principais cidades do mundo de acordo com seu magnetismo ou seu poder abrangente para atrair pessoas, capital e empresas de todos os continentes, através da medição de seis funções capazes de fornecer uma classificação multidimensional: Economia, Pesquisa e Desenvolvimento, Interação Cultural, Qualidade de vida, Meio Ambiente e Acessibilidade, totalizando 70 subdivisões pesquisadas. Da América Latina, duas cidades são citadas: Buenos Aires, em $38^{\circ}$ lugar, e São Paulo, em $40^{\circ}$, do total de 44 cidades mundiais analisadas (Yamato et al., 2018).

O Quality of Living City Ranking 2018 (QLCR), publicado anualmente pela MERCER (2019), avalia 450 cidades em todo o planeta, de acordo com 39 fatores, agrupados em dez categorias. O ranking de 2019 avaliou 231 cidades, onde Viena ocupa a posição de liderança pelo nono ano consecutivo, e Londres aparece em $41^{\circ}$ lugar. Quatro cidades brasileiras são citadas no ranking de 2019, sendo Brasília em $107^{\circ}$; Rio de Janeiro $\left(118^{\circ}\right)$, São Paulo $\left(119^{\circ}\right)$ e Manaus $\left(127^{\circ}\right)$. Como este índice utiliza comparações de Qualidade de Vida de diferenças relativas a dois locais (entre uma cidade-base e uma cidadesede), é possível que muitas localizações não tenham sido avaliadas, e nos últimos 2 anos a cidade de Curitiba não apareceu na lista geral das cidades (MERCER, 2019).

O Global Liveability Index (GLI), da Economist Intelligence Unit (EIU), analisa 140 cidades do mundo todo, do ponto de vista qualitativo e quantitativo de cinco categorias (governança/estabilidade, saúde, cultura e meio ambiente, educação e infraestrutura) e seus subitens. Viena, na Áustria, é classificada como a cidade número um mais habitável do 
mundo, pelo ranking 2018, sendo a primeira vez que a cidade se encontra nessa posição na lista. Melbourne, na Austrália, manteve a posição por sete anos seguidos e foi classificada em segundo lugar (THE ECONOMIST GROUP, 2018).

O Sustanaible City Index (SCI), analisa 100 cidades sob a perspectiva do cidadão, baseado em 3 pilares de sustentabilidade: Pessoas (social), Planeta (ambiental) e Lucro (econômico), e seus subitens. Da América Latina, na edição de 2018, a cidade de Santiago (Chile) está na $77^{\mathrm{a}}$ posição, seguida de São Paulo (Brasil) na 78 ${ }^{\mathrm{a}}$, Buenos Aires (Argentina, $81^{\mathrm{a}}$ ), Rio de Janeiro (Brasil, 84ª), Lima (Peru, 85 ) e Salvador (Brasil, 86 ) (ARCADIS, 2018).

Quando se comparam apenas cidades brasileiras, o Ranking Connected Smart Cities é o mais indicado, considerando todos os aspectos que analisa, e por estarem todas submetidas ao mesmo país, considerando seus aspectos geográficos, políticos e legais (Urban Systems, 2018).

\subsection{Curitiba e suas características}

Apontada como uma das cidades mais inteligentes e conectadas do Brasil pelo Ranking Connected Smart Cities, elaborado pela Urban Systems (2018), Curitiba ocupa o $140^{\circ}$ lugar no índice da University of Navarra CIMI 2018, ver Figura 1 (Berrone et al.,2019).

Figura 1. Classificação de Curitiba no IESE Cities in Motion Index, 2019.
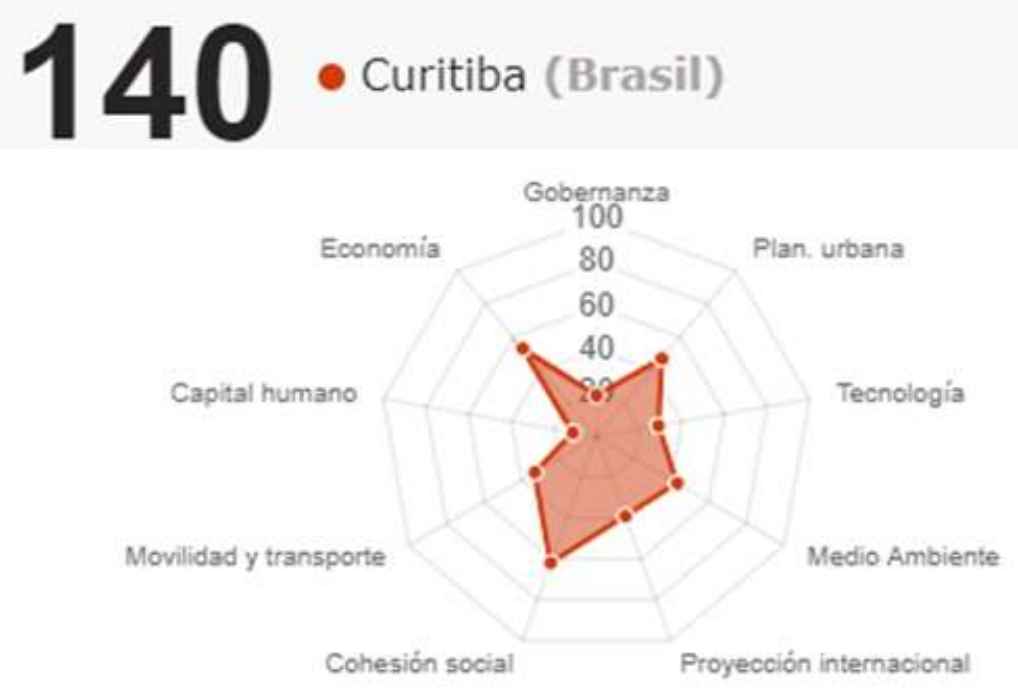

Fonte: Berrone et al. (2019).

Comparativamente em relação a São Paulo, analisado no IESE Cities in Motion Index, 2019, a cidade de Curitiba (com 1,9 milhão de habitantes, densidade demográfica de 4027 hab/km2 e 53,1\% da população ocupada), tem mais pontuação em mobilidade e transporte, coesão social e meio ambiente (Berrone et al., 2019).

Já a capital de São Paulo (12,18 milhões de habitantes estimados em 2018 pelo IBGE; densidade demográfica de 7398 hab/km2, e 46,8\% da população ocupada) pontua melhor que Curitiba em projeção internacional, planejamento urbano, tecnologia economia, governança e capital humano. A Figura 2 mostra a comparação entre as duas cidades (Berrone et al., 2019). 
Figura 2. Classificação Comparativa entre Curitiba e São Paulo no IESE Cities in Motion Index, 2019.

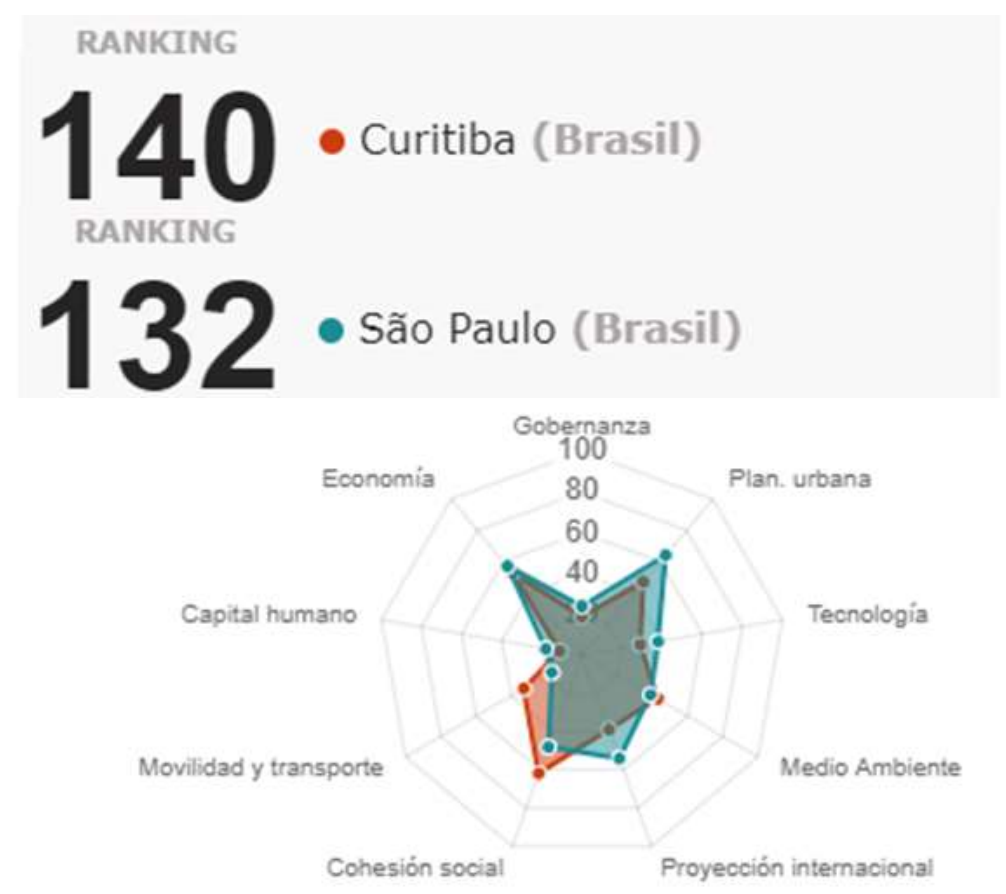

Fonte: Berrone et al. (2019).

Curitiba é uma das cidades mais verdes do país, com uma rede de quase 30 parques e áreas florestais, e possui 76,1\% de domicílios urbanos em vias públicas com arborização e 59,1\% de domicílios urbanos em vias públicas com urbanização adequada (presença de bueiro, calçada, pavimentação e meio-fio) (Urban Systems, 2018; Alves, 2018).

A cidade de Curitiba apresenta 96,3\% de domicílios com esgotamento sanitário adequado, sendo que $70 \%$ dos resíduos produzidos pelos habitantes é reciclado, havendo programas de incentivo como o Câmbio Verde, onde a população pode trocar seu lixo reciclável por frutas e verduras frescas. E possui um sistema de transporte urbano rápido e efetivo, utilizado por cerca de $70 \%$ da população, sendo que os ônibus antigos são reaproveitados e transformados em escolas móveis de educação para a sustentabilidade (Urban Systems, 2018; Alves, 2018).

Curitiba também apresenta melhor Índice de Desenvolvimento Humano-IDH (0,823 em 2010) do que São Paulo $(0,805)$ no mesmo período. Curitiba é uma das melhores cidades do Brasil para se viver (Urban Systems, 2018).

\subsection{Migrando de uma gestão tradicional para uma cidade inteligente}

No entender do BID, uma CIS deve ser capaz de (Bouskela et al., 2016):

i. Gerar integração, que por sua vez forneça informações à administração pública necessária e transparente para uma melhor tomada de decisão e gerenciamento de orçamento;

ii. Permitir melhor atenção aos usuários dos serviços e melhor imagem dos órgãos públicos e, assim, elevar o grau de satisfação dos habitantes;

iii. Otimizar a alocação de recursos e ajudar a reduzir despesas desnecessárias;

iv. Gerar procedimentos comuns que aumentam a eficiência do governo;

v. Produzir indicadores de desempenho que são úteis para medir, comparar e melhorar políticas públicas; 
vi. Permitir maior participação da sociedade civil organizada e dos cidadãos na administração através do uso de ferramentas tecnológicas que ajudam a monitorar os serviços públicos, identificando informando e interagindo com a administração municipal, para resolvê-los.

Segundo o BID, o projeto de uma solução inteligente para uma cidade requer (Bouskela et al., 2016):

a) Identificar os recursos tecnológicos necessários para o desenvolvimento de projetos que tenham impacto;

b) Definir o plano estratégico com implementação por etapas do projeto;

c) Encontrar fontes de financiamento;

d) Mapear benefícios para os cidadãos.

Para a transformação de cidades em emergentes e sustentáveis, há necessidade de desenvolvimento de um plano de ação, capaz de identificar os principais desafios da sustentabilidade através da análise de indicadores, sendo este plano de ação dividido em cinco etapas (Bouskela et al., 2016):
1. Diagnóstico;
2. Priorização;
3. $\quad$ Elaboração do plano de ação;
4. Pré-inversão;
5. Monitoramento.

Estas etapas são divididas em duas fases, sendo a primeira relacionada ao desenvolvimento do plano propriamente dito (proposto pelo BID com duração de um ano), e a segunda, a execução do plano de ação (proposto pelo BID em 3 anos). $\mathrm{Na}$ primeira fase, estariam as sub-etapas preparação, análise e diagnóstico, priorização, e a criação do plano de ação propriamente dito. Já na fase seguinte, as sub-etapas seriam pré-inversão, monitoramento, inversão (Bouskela et al., 2016).

Segundo Nam e Pardo (2011), são elencados os componentes fundamentais de uma CIS, e suas direções estratégicas devem levar em conta fatores humanos, tecnológicos e institucionais (Quadro 6). Entretanto, segundo, o gerencimento de projeto de uma cidade inteligente deve contar com a harmonização entre os mundos virtual e material, respeitando-se as vocações particulares de cada CIS (Weiss et al., 2013b).

Quadro 6. Arquitetura de Sistemas de Gerenciamento para CIs.

\begin{tabular}{|c|c|c|c|c|c|c|}
\hline \multirow{9}{*}{ 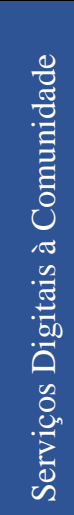 } & \multirow{2}{*}{\multicolumn{6}{|c|}{ Poder Público - Estratégia e Planejamento }} \\
\hline & & & \multicolumn{4}{|c|}{ Governança \& Gestão } \\
\hline & Informaçõ & nciais & \multicolumn{2}{|c|}{ Conformidade \& Riscos } & Finanças & $\begin{array}{l}\text { Ativos \& } \\
\text { Suprimentos }\end{array}$ \\
\hline & \multirow{2}{*}{\multicolumn{6}{|c|}{$\begin{array}{l}\text { Gerenciamento dos Serviços Públicos } \\
\text { Centro Integrado de Operações }\end{array}$}} \\
\hline & & & & & & \\
\hline & \multicolumn{4}{|c|}{ Serviços à Comunidade } & \multicolumn{2}{|c|}{ Infraestrutura Pública } \\
\hline & Saúde & Segurança & Educação & $\begin{array}{l}\text { Transportes \& } \\
\text { Tráfego }\end{array}$ & Energia & $\begin{array}{c}\text { Água \& } \\
\text { Saneamento }\end{array}$ \\
\hline & Informações & $\begin{array}{l}\text { Suporte \& } \\
\text { Ouvidoria }\end{array}$ & Mobilidade & Meio ambiente & $\begin{array}{l}\text { Edifícios \& } \\
\text { Espaços }\end{array}$ & Resíduos \& Lixo \\
\hline & \multicolumn{6}{|c|}{ Infraestrutura de Tecnologia da Informação e Comunicação } \\
\hline
\end{tabular}

Fonte: Weiss et al. (2013b).

\subsection{Características de Curitiba e São Luís}

A mortalidade infantil (MI) ocorre como consequência de uma combinação de fatores biológicos, sociais, culturais e de falhas do sistema de saúde e, portanto, as intervenções dirigidas à sua redução dependem tanto de mudanças estruturais 
relacionadas às condições de vida da população, assim como de ações diretas definidas pelas políticas públicas de saúde (França \& Lansky, 2008).

A mortalidade infantil apresenta relações já bem estabelecidas na literatura com uma série de fatores: condições biológicas maternas e infantis (idade da mãe, paridade, intervalo entre os partos, prematuridade, baixo peso ao nascer, retardo no crescimento intrauterino etc.); condições ambientais (existência dos serviços de saúde e da acessibilidade da população a eles, abastecimento de água potável e saneamento básico adequado, poluição etc.) e, fundamentalmente, as relações sociais que organizam a vida concreta das pessoas (moradia, trabalho, renda, nível de informação, proteção social etc.) (Duarte, 2007).

Entretanto, quando se analisa o item saúde, no Ranking Connected Smart Cities, São Luís teve ganho de mais de 100\% em sua classificação de 2018 em relação a 2017, saltando de $555^{\circ}$ lugar para $247^{\circ}$ entre os municípios analisados, enquanto Curitiba subiu de $34^{\circ}$ para $33^{\circ}$ lugar (Urban Systems, 2018).

Considerando-se as regiões geográficas, Curitiba encontra-se no Sul, enquanto que São Luís faz parte da região Nordeste, sendo que as diferenças regionais são consideradas neste ranking. Primeiro lugar no Brasil, Curitiba também encontra se na mesma posição, quando analisada por região, enquanto que da região Nordeste não há nenhuma classificada, conforme Figura 2 (Urban Systems, 2018).

Entretanto, por apresentarem maior desenvolvimento econômico, as cidades do Centro-Sul brasileiro contam com desenvolvimento social maior do que as cidades do Norte e Nordeste do país, impactando nos resultados dos eixos de meio ambiente, educação, saúde, estes mais básicos, porém com consequente impacto nos eixos de empreendedorismo, tecnologia e inovação e economia (Urban Systems, 2018).

\subsection{São Luís atual}

Somente em 1936 é que a cidade de São Luís se preocupou com o zoneamento urbano, através da edição do Decreto Municipal n 496, de 14 de julho de 1936, embora antes já houvessem códigos de posturas, mais preocupados com as fachadas dos prédios e ruas (Vale, 2018). Dois anos depois surgiu o segundo zoneamento urbano da cidade, criando os primeiros afastamentos e recuos obrigatórios, separando a cidade por funções e determinando ainda o número máximo de pavimento das construções para cada zona, na região central da cidade (Vale, 2018).

Com o adensamento populacional foi necessário que a mesma se expandisse e surgiu o Plano de Expansão da Cidade de São Luís, na década de 60, o que gerou o crescimento em três eixos (praia ao norte, zona industrial ao sul, e conjuntos habitacionais no sentido do bairro do Anil) e exigiu a manutenção de grandes áreas verdes (Vale, 2018).

Em 1975, o Estado criou mais dois instrumentos: o Plano Diretor e o Zoneamento (atualizada posteriormente em 1981). Com a Constituição Federal de 1988, trazendo artigos que tratam da questão urbana de forma exclusiva, surgiram os Planos Diretores e de Zoneamento de 1992, onde a ideia de gestão urbana ganhou força, ocupando o lugar do planejamento urbano, a fim de proporcionar maior equidade aos habitantes (Brasil, 1988).

Dentro deste contexto surgiu, em 2006, um novo Plano Diretor, englobando as assertivas do Estatuto das Cidades (lei 10.257, de 10 de julho de 2001) (Brasil, 2001), e o Estatuto das Metrópole (Lei 13.089 de 12 de janeiro de 2015) (Brasil, 2015).

A cidade é mais planejada hoje do que jamais foi, mas os problemas se mantêm e se expandem. Congestionamentos, déficit habitacional e infraestrutura precária são problemas recorrentes em São Luís. Em boa parte, o próprio planejamento urbano criou ou potencializou esses efeitos. Ao criar uma cidade dispersa, ele favoreceu o uso do carro, criando congestionamentos (Vale, 2018). Ao restringir índices construtivos, impediu o mercado de criar habitação a preço mais acessível. E novamente, a cidade dispersa aumentou os custos com infraestrutura e a distância entre periferia e centro. 
As regulações e restrições do uso do solo e exigências construtivas elevaram o valor da terra, fazendo com que as pessoas, em busca de terra barata, se mudassem para regiões cada vez mais distantes (Vale, 2018). A alternativa para morar em áreas centrais foi a ocupação de terras (em sua maioria públicas e de proteção ambiental), como é o caso do bairro do Coroadinho, maior favela do Norte e Nordeste do Brasil (Vale, 2018).

Em reportagem reproduzida em 2017, pelo jornal de circulação nacional O Imparcial, há o relato do uso de prédios históricos do centro da cidade para estacionamento, onde os casarões históricos definham com a ação do tempo e os proprietários, visando lucro, destroem a parte interna das edificações, transformando em espaço para estacionamento (Furtado, 2017). Nas fachadas de alguns edifícios históricos, há pichações, que afetam de forma negativa o status visual dos prédios. A circulação de pedestres é comprometida porque os proprietários de imóveis vão construindo as calçadas da forma que melhor os servirá, mas são poucos os que pensam na coletividade, no deslocamento de todas as pessoas, incluindo idosos e deficientes físicos (Furtado, 2017).

Este cenário faz com que as pessoas prefiram andar na sarjeta, ou na pista, mesmo correndo risco de serem atingidas por carros. Ainda em relação às vias públicas, há a implantação de galerias de escoamento das águas feitas em locais inadequados e não protegidas contra acidentes, tornando a circulação de pedestres e veículos bastante arriscada (Furtado, 2017).

Normalmente, os cortiços são formados por casarões em risco de desabamento, devido à ausência de reformas e manutenção. Os moradores que ali residem se encontram em total estado de vulnerabilidade, isto no sentido mais amplo da palavra (Sousa, Rodrigues e Oliveira, 2019).

São Luís, no que tange à extensão da malha cicloviária, é a penúltima em classificação no País (18 km), ficando à frente apenas de Macapá (11,9 km), segundo levantamento realizado em fevereiro de 2017 pelo portal G1. Quando se realiza o comparativo entre a quilometragem e o número de habitantes, o portal G1 destaca que novamente São Luís é a penúltima na classificação das capitais do País (60.653 hab/km de ciclovia), ficando à frente apenas de Manaus (102.165 hab/km de ciclovia). Curitiba possui 204,2 km de extensão e 9.275 hab/km de ciclovia, aparecendo em quinto lugar na classificação, em ambos itens (Jornal Pequeno, 2017).

O Plano Estadual de Saúde (PES 2016-2019) é um dos principais instrumentos da gestão estadual, inicialmente, porque reflete as necessidades e peculiaridades regionais no âmbito da saúde, e tem a finalidade de apoiar as gestões na condução da prestação de ações e serviços de saúde de modo que alcance a melhoria dos níveis de saúde da população em cada esfera de governo (PES, 2016).

O PES enfoca, no capítulo Situação Diagnóstica da região de saúde, a cidade de São Luís, que dispõe de maior resolubilidade diante dos demais municípios do Estado. No que se refere aos atendimentos em Média e Alta Complexidade, constata-se que existe maior concentração de serviços, considerando os equipamentos de alta tecnologia e recursos humanos especializados existentes na capital (PES, 2016).

Na educação, investimentos ainda são necessários, pois a situação das escolas da rede municipal de São Luís é crítica, segundo reportagem do jornal O Estado, em 22 de abril de 2017. No texto, há a informação de que 90\% das escolas municipais estão em péssimo estado de conservação, comprometendo a aprendizagem dos estudantes (Santos, 2017).

Quanto à moradia, visando garantir condições de habitabilidade, a Secretaria de Estado das Cidades e Desenvolvimento Urbano está realizando intervenções na área de habitação e urbanismo na cidade de São Luís. De acordo com informações da Agência de Notícias do Governo do Estado do Maranhão, estão sendo construídos mais de mil apartamentos para abrigar famílias que viviam em condições de vulnerabilidade social nos bairros da Liberdade, Camboa e entorno da Avenida Jackson Lago (Maranhão, 2019). 
Há mais 300 habitações em obras na região do Itaqui-Bacanga. Há outras 256 no bairro da Ilhinha, para abrigar famílias que moravam em palafitas no bairro do São Francisco. Quanto à urbanização, a Avenida Jackson Lago deverá ganhar uma Unidade Básica de Saúde, praças e uma Unidade de Segurança Cidadã (Maranhão, 2019).

Em 2013, a prefeitura de São Luís em conjunto com a empresa de consultoria brasileira MACROPLAN lançaram os resultados de uma pesquisa realizada com gestores, a respeito das necessidades e percepções da cidade, onde os principais temas que emergiram dizem respeito à mobilidade, infraestrutura urbana, gestão eficiente, desenvolvimento econômico, centro histórico e educação, sedo seguido por comportamento dos cidadãos e saúde, e tendo sido os menos citados temas relacionados à segurança, integração metropolitana e inclusão e justiça social (Prefeitura de São Luís, MACROPLAN, 2013).

\section{Metodologia}

\subsection{Materiais}

Foram utilizados dados abertos encontrados no site do IBGE, na internet, referentes às cidades brasileiras de Curitiba e São Luís. Foram utilizados ainda os dados do Ranking Connect Smart Cities (2018), para apontar as características de cada uma das duas cidades comparadas. As bases de dados consultadas não contemplaram informações sigilosas, como nomes e endereços, de modo que foi dispensada a aprovação do projeto de estudo por um comitê de ética em pesquisa.

\subsection{Delineamento do estudo}

Trata-se de uma pesquisa aplicada, quali-quantitativa, exploratória (Silva, \& Menezes, 2005). Ela é aplicada por ser direcionada à resolução de um problema específico, sendo qualitativa por depender de um conceito fundamentado em Cidades Inteligentes e da definição de seus indicadores. Também é quantitativa na medida em que aplica o sistema, considerando os novos indicadores sugeridos; e é exploratória por envolver as normativas nacionais e internacionais, as características das cidades e sua evolução (através de revisão bibliográfica). Há proposta de um plano de intervenção, ao final, a fim de tornar São Luís mais competitiva no que tange à sua classificação como CIS.

Utilizaram-se os seguintes dados do IBGE: População; Pesquisa Nacional de Saneamento Básico 2008; Finanças Públicas; MUNIC- Suplemento Meio Ambiente; Taxa de mortalidade infantil; Rampa para cadeirante de acesso ao entorno da residência; Existência de lei de zoneamento ou uso e ocupação do solo; Existência de lei sobre operação urbana consorciada (urbanismo); Existência de lei sobre plano diretor estratégico municipal; Disponibilidade de emissão de certidão negativa de débito e alvará no site da prefeitura; Percentual de domicílios localizados em áreas pavimentadas; Proporção de domicílios que declararam arborização ao entorno; Percentual de domicílios com existência de energia elétrica de outra fonte diferente da companhia distribuidora; Presença de iluminação pública no entorno da residência; Presença de energia elétrica no domicílio; Número de médicos por habitante; Possibilidade de matrícula escolar na rede pública, on line; Relação do número de vagas sobre a população com idade superior a 18 anos, em universidades públicas; Existência dos seguintes conselhos municipais: educação, saúde, direitos humanos, segurança pública, defesa civil e segurança alimentar; PIB per capita; Empregabilidade (relação de empregos formais existentes no município e habitantes com idade entre 18 e 60 anos).

Nos dados do Ranking Connect Smart Cities, foi realizado levantamento das seguintes variáveis: Mobilidade e acessibilidade; Urbanismo; Meio ambiente; Energia; Tecnologia e inovação; Saúde; Segurança; Educação; Empreendedorismo; Governança; Economia.

Os componentes fundamentais de uma CIS, e suas direções estratégicas são apresentados na Figura 3. 
Figura 3. Componentes de cidades inteligentes e direções estratégicas.

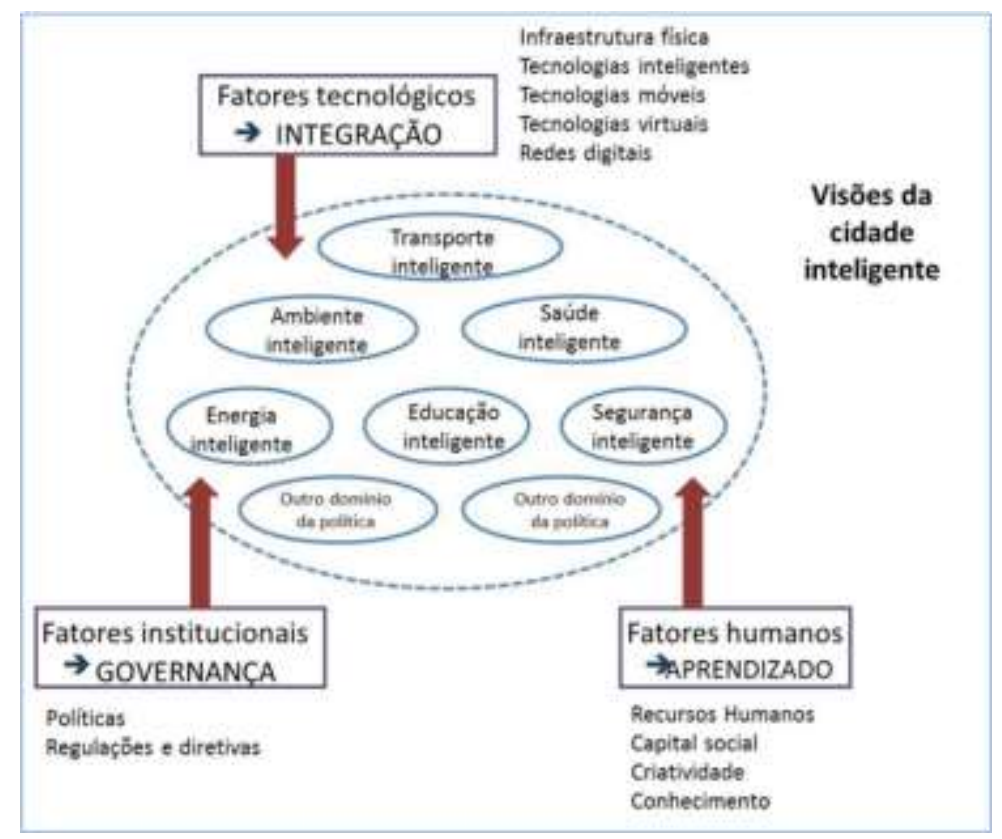

Fonte: Nan e Pardo (2011).

Após o levantamento de dados das cidades de Curitiba e de São Luís, estes foram processados, analisados e comparados, para em seguida propor um Plano de Ação prioritário, visando facilitar a transformação de São Luís numa CIS.

Os resultados encontrados visam a aplicação, com base na capacidade de desenvolvimento da cidade.

Desta mesma fonte, foram utilizados os 70 indicadores analisados no Ranking Connected Smart Cities, (2018):

\section{1- Mobilidade e acessibilidade:}

- Proporção de automóveis/habitantes: Dado que pondera a proporção de veículos do tipo automóvel em relação a quantidade de habitantes na cidade. Fonte: DNIT, dez/17;

- Idade média da frota de veículos: Dado que ponderou a idade média da frota disponível (emplacada) nos municípios. Está atrelado a qualidade e velocidade da mobilidade e também a questão de saúde, uma vez que veículos mais antigos tendem a poluir mais, segundo estudos. Fonte: DNIT, dez/17;

- Automóveis/ônibus: Dado que pondera a proporção de veículos do tipo automóvel em relação a quantidade de veículos do tipo ônibus e micro-ônibus. Fonte: DNIT, dez/17;

- Outros modais de transporte coletivo: Levantamento individual das cidades que possuem algum modelo a mais, do que o simples transporte de passageiros por sistema de transporte público tradicional. Quilômetros desse modal por cem mil habitantes. Fonte: CPTM / Metro Rio / Metro SP / entre outras, 2018;

- Ciclovias: Informação de quilômetros de ciclovias implantadas por cem mil habitantes. Dado municipal mais recente disponível na data de corte. Fonte: Mobilize + Outros, jun/18;

- Rampa para cadeirante: Dado relativo a proporção de domicílios que possuem rampa de acesso em seu entorno, qualificando a acessibilidade dos municípios. Fonte: IBGE, 2010;

- Número de voos semanais: Informação referente aos diferentes destinos regulares semanais realizados pelos aeroportos em operação, grandeza que qualifica o poder de conectividade dos municípios. Fonte: Hotran / ANAC, jun/18;

- Transporte rodoviário: Dado que refere-se a conectividade rodoviária, tendo sido considerada as seções existentes nas linhas regulares de transporte interestaduais. Fonte: ANTT, jun/18; 


\section{$\underline{\text { 2- Urbanismo }}$}

- Lei sobre zoneamento ou uso e ocupação do solo: Considerada essencial para o correto ordenamento do solo em uma cidade, foi gerada uma escala em relação as informações disponíveis quanto a existência da lei, seu contexto e ano de publicação mais recente. Fonte: IBGE, 2014 atualizadas em jun/18;

- Lei sobre operação urbana consorciada: Também considerada importante para impulsionar o desenvolvimento de regiões da cidade e investir em infraestrutura, foi gerada uma escala em relação às informações disponíveis quanto a existência da lei, seu contexto e ano de publicação mais recente. Fonte: IBGE, 2014 atualizadas em jun/18;

- Lei de plano diretor estratégico municipal: Lei considerada um instrumento básico da política do desenvolvimento do município, foi gerada uma escala em relação as informações disponíveis quanto a existência da lei: IBGE, 2014 atualizadas em jun/18;

- Emissão de certidão negativa de débito e alvará no site da prefeitura: Disponibilidade do serviço de forma online no site da prefeitura e/ou secretaria. Fonte: IBGE, 2015;

- Vias pavimentadas: Percentual de domicílios que estão localizados em áreas com presença de ruas pavimentadas no entorno. Fonte: IBGE, 2010;

- Despesa municipal com urbanismo: Relação entre as despesas pagas por função urbanismo e o total de habitantes no município. Fonte: Siconfi/Finbra, 2017, 2016 e 2015;

- Meio ambiente índice de atendimento urbano de água: Percentual do total da população urbana atendida com abastecimento de água. Fonte: SNIS, 2016;

\section{$\underline{\text { 3- Meio ambiente }}$}

- Paralisação do abastecimento: Quantidade de horas, no ano, em que ocorreram paralisações no sistema de distribuição de água. Devem ser somadas somente as durações de paralisações que, individualmente, foram iguais ou superiores a seis horas. Fonte: SNIS, 2016;

- Índice de perdas na distribuição de água: Volume de água (produzido tratado importado de serviço) reduzido o volume de água consumido, ambos sobre o volume de água (produzido tratado importado de serviço). Fonte: SNIS, 2016;

- Índice de atendimento urbano de esgoto: Percentual da população urbana atendida com esgotamento sanitário sobre a população urbana do(s) municípios(s) atendido(s) com abastecimento de água. Fonte: SNIS, 2016;

- Índice de tratamento urbano de esgoto: Percentual do esgoto urbano tratado sobre total de esgoto coletado. Fonte: SNIS, 2016;

- Taxa de recuperação de materiais recicláveis: Relação da quantidade total de materiais recuperados (exceto matéria orgânica e rejeitos) sobre a quantidade total de resíduos coletada. Fonte: SNIS, 2016;

- Taxa de cobertura do serviço de coleta de resíduos domésticos: Relação da população total atendida pelo serviço de coleta de resíduos pela população total do município. Fonte: SNIS, 2016;

- Arborização: Dado relativo a proporção de domicílios que declararam possuir arborização em seu entorno. Fonte: IBGE, 2010;

- Monitoramento de áreas de risco: Cidades que possuem mapeamento de suas áreas de risco de movimentos de massa, como deslizamentos de encosta, corridas de massa, solapamentos de margens/terras caídas, queda/rolamento de blocos rochosos e processos erosivos, bem como das áreas de risco hidrológicos, inundações e enxurradas, além da estimativa da extensão dos prováveis danos decorrentes de um desastre natural. Fonte: CEMADEN, 2016; 


\section{4- Energia}

- Tarifa média: Ponderação do valor da tarifa média no município, considerando que o valor da tarifa está atrelado a investimentos e perdas. Fonte: ANEEL, 2018;

- Domicílios com existência de energia elétrica de outra fonte diferente de companhia distribuidora: Percentual de domicílios particulares permanentes com fonte de energia elétrica diferente de companhia de distribuição. Fonte: IBGE, 2010;

- Produção de energia em usinas de energia eólica: Potência outorgada em produção de energia em usinas de energia eólica nas usinas em operação no município, para qualquer fim. Fonte: ANEEL, jun/18;

- Produção de energia em usinas de UFV: Potência outorgada em produção de energia em usinas de energia solar fotovoltaica nas usinas em operação no município, para qualquer fim. Fonte: ANEEL, jun/18;

- Produção de energia em usinas de biomassa: Potência outorgada em produção de energia em usinas de energia eólica nas usinas em operação no município, para qualquer fim. Fonte: ANEEL, jun/18;

- Iluminação pública: Dado relativo à proporção de domicílios que possuem iluminação pública em seu entorno. Fonte: IBGE, 2010;

- Domicílios com existência de energia elétrica: Domicílios particulares permanentes com existência de energia elétrica. Fonte: IBGE, 2010;

\section{5- Tecnologia e inovação}

- Conexões de banda larga com + de $34 \mathrm{mb}$ : Porcentagem de acessos de conexão de banda larga com faixa superior a $34 \mathrm{Mb}$ em relação ao total de acessos de conexão de banda larga. Fonte: Anatel, dez/17;

- Municípios com backhaul de fibra ótica: Municípios com infraestrutura de conexão dos pontos de concentração da rede de acesso com o núcleo de alta capacidade de transmissão da rede, também conhecido como backbone. Indicador pela contagem de empresas com infraestrutura na cidade. Fonte: Ministério das Comunicação, 2018;

- Cobertura 4G: Municípios com cobertura de 4G. Grandeza com escala por quantidade de operadoras que oferecem o serviço, de 1 a 5. Fonte: Teleco, jun/18;

- Trabalhadores com ensino superior: Porcentagem de trabalhadores formais empregados em dezembro de 2013 com ensino superior completo, sobre o total de trabalhadores formais empregados no município. Fonte: RAIS, 2016;

- Acessos no serviço de comunicação multimídia: Quantidade de acessos do serviço de comunicação multimídia por cem mil habitantes. Fonte: Anatel, mar/17;

- Patentes: Depósitos de patentes do tipo Patentes de Invenção (PI) e Patente de Modelo de Utilidade (MU) por cem mil habitantes Fonte: INPI, 2017;

- Bolsas CNPQ: Valor total das Bolsas do tipo Pesquisa pagas. Fonte: CNPQ, 2016

\section{6- Saúde}

- Leitos por habitantes: Número de leitos hospitalares existentes por mil habitantes. Métrica considerada para comparar a oferta de infraestrutura de saúde. Fonte: Datasus, dez/17;

- Médicos por habitantes: Número de médicos (profissionais com Classificação Brasileira de Ocupações - CBO do tipo médico, médico clínico, médico em especialidade cirúrgica, médicos em medicina diagnóstica e terapêutica) sobre o total da população do município. Fonte: RAIS / IBGE, 2016;

- Cobertura populacional da equipe de saúde da família: Proporção de cobertura populacional estimada pela Equipe de Saúde da Família. Fonte: Min Saúde da Saúde, mar/17;

- Despesa municipal com saúde: Relação entre a despesas paga por função saúde e o total de habitantes no município. 
Fonte: Siconfi/Finbra, 2016 e 2015;

- Mortalidade infantil: Óbitos a cada mil nascidos vivos (local de residência da mãe). Fonte: Datasus, 2012 a 2016;

\section{7- Segurança}

- Homicídios: Taxa municipal de homicídios por cem mil habitantes. Causa - CID-BR-10: 110 Agressões, 111 Eventos (fatos) cuja intenção é indeterminada, 112 Intervenções legais e operações de guerra. Fonte: Datasus, 2018;

- Acidentes de trânsito: Taxa municipal de homicídios por cem mil habitantes. Causa - CID-BR-10: 104 Acidentes de transporte. Fonte: Datasus, 2018;

- Despesa municipal com segurança: Relação entre a despesas paga por função segurança e o total de habitantes no município. Fonte: Siconfi / Finbra, 2016 e 2015;

- Policiais, guardas-civis municipais e agentes de trânsito: Número de policiais sobre o total da população do município. Fonte: RAIS, 2016;

\section{$\underline{\text { 8- Educação }}$}

- Matrícula escolar na rede pública online: Existência de serviço de matrícula escolar na rede pública de forma online. Dado em escala de valor. Fonte: IBGE, 2015;

- Vagas em universidade pública: Relação do número de vagas em instituições de ensino superior públicas sobre o total de população com idade superior a 18 anos. Fonte: INEP / IBGE, 2015;

- Nota ENEM: Nota média ponderada do ENEM por município. Fonte: INEP, 2017;

- Docentes com ensino superior: Percentual dos docentes do ensino médio que possuem ensino superior completo. Fonte: INEP, 2017;

- IDEB - Anos finais: Índice de Desenvolvimento da Educação Básica (Ideb) em anos finais. Fonte: INEP, 2017;

- Taxa de abandono: Índice de abandono no ensino médio para ensino público. Fonte: INEP, 2017;

- Média de alunos por turma: Média de alunos por turma no $9^{\circ}$ ano do ensino fundamental público. Fonte: INEP, 2017 ;

- Despesa municipal com educação: Relação entre a despesas paga por função educação e o total de habitantes no município. Fonte: Siconfi / Finbra, 2016 e 2015;

- Hora-aula diária média: Hora-aula diária média de todas as dependências administrativas no Ensino Fundamental 8 e 9 anos. Fonte: INEP, 2017;

\section{9- Empreendedorismo}

- Novas empresas de tecnologia: Crescimento no número de empresas das classes CNAE 6201 (desenvolvimento de programas de computador sob encomenda), 6202-3 (desenvolvimento e licenciamento de programas de computador customizáveis) e 6203-1 (desenvolvimento e licenciamento de programas de computador não-customizáveis). Fonte: RAIS, 2016;

- Polos tecnológicos: Número de polos tecnológicos existentes por município Fonte: Anprotec, 2017;

- Crescimento empresas de economia criativa: Crescimento das 44 Classes CNAE que compõe os 10 setores da economia criativa. Fonte: RAIS, 2016;

- Incubadoras: Número de empreendimentos do tipo incubador de negócios e projetos existente nos municípios. Fonte: Anprotec, 2017;

- Micro empresas individuais (MEI): Crescimento da soma do número de microempreendedores individuais 
formalizados no portal empreendedor e dos empresários individuais microempresas que optaram pelo SIMEI no início do exercício fiscal. Fonte: Portal do Empreendedor, 2017;

\section{0-Governança}

- Escolaridade do prefeito; Informação em escala, com o nível mais alta de escolaridade do prefeito. Fonte: TSE, 2017;

- Índice FIRJAN de Desenvolvimento Municipal: Estudo do Sistema FIRJAN que acompanha anualmente o desenvolvimento socioeconômico dos municípios brasileiros nas áreas de atuação: Emprego e renda, Educação e Saúde. Fonte: Firjan, 2016 (2014);

- Escala brasil transparente: Indicador utilizado para medir a transparência pública em estados e municípios brasileiros, desenvolvida para avaliar o grau de cumprimento de dispositivos da Lei de Acesso à Informação. Fonte: CGU, $3^{\mathrm{a}}$ edição;

- Conselhos municipais: Indicador que avalia a existência de canais participativos para os principais setores de desenvolvimento municipal. Foram considerados e pontuados os conselhos municipais de: educação, saúde, direitos humanos, segurança pública, defesa civil e segurança alimentar. Fonte: IBGE, 2015;

\section{$\underline{11-E c o n o m i a}$}

- PIB PER CAPITA: Crescimento do produto interno bruto dividido pela quantidade de habitantes do município último dado disponível. Fonte: IBGE, 2015;

- Renda média dos trabalhadores: Renda média do total de trabalhadores formais empregados no município em dezembro de 2014. Fonte: RAIS, 2016;

- Crescimento empresarial: Crescimento do número de empresas formais no período descrito. Fonte: RAIS, 2016;

- Crescimento dos empregos formais: Crescimento do número de empregos formais no período descrito. Fonte: RAIS 2016 e CAGED jun/18;

- Empregos independentes do setor público: Relação inversa da proporção de empregos no subsetor da administração pública. Busca identificar a dependência ou independência de um município em relação aos empregos na administração pública. Permite identificar dinamismo econômico. Fonte: RAIS, 2016;

- Empregabilidade: Relação de empregos formais existentes no município e habitantes com idade entre 18 e 60 anos. Fonte: RAIS / IBGE, 2016;

- Receitas Municipais não Oriundas de Transferências (Economia): com o intuito de avaliar a maturidade econômica dos municípios, esse indicador avalia o percentual de receitas do município excetuando as Transferências Correntes que incluem: transferências da União, dos Estados e dos Municípios. Fonte: Siconfi / Finbra, 2016.

\section{Resultados e Discussão}

Neste tópico é realizada a análise dos eixos temáticos de Curitiba e de São Luís, bem como uma proposta de soluções e de plano de ação prioritário para São Luís, considerando os aspectos mobilidade urbana, meio ambiente, saúde, tecnologia e inovação, segurança. A proposta de ação considera os aspectos ligados à gestão da administração pública, gestão do saneamento, e ainda a adequação e uso do território.

\subsection{Análise dos eixos temáticos de Curitiba e de São Luís}

Por se tratar de análise baseada em dados de um ranking que pode, a cada evento, modificar a posição ocupada pelas 
cidades, e por estas cidades serem dinâmicas quanto aos aspectos analisados, há limitações de estudo por não haverem dados que possam ser inseridos no exato momento.

Quando se tratam de cidades brasileiras, compará-las a outros países é díspar quanto às peculiaridades de cada nação. Por isso, o Ranking Connected Smart Cities e os dados do IBGE foram utilizados nesta comparação, a fim de que se possam discutir seus resultados e traçar as metas para São Luís.

Considerada em primeiro lugar em 2018, no Ranking Connected Smart Cities a cidade de Curitiba, ocupava o segundo lugar em 2017 e, apesar disto, está classificada em posições diferentes quando seus eixos temáticos são analisados (Tabela 1).

Tabela 1. Classificação da cidade de Curitiba, em 2017 e 2018.

\begin{tabular}{lcc}
\hline & Curitiba & \\
\hline Posição & 2017 & 2018 \\
Connected Smart Cities & 2 & 1 \\
Mobilidade e Acessibilidade & 4 & 7 \\
Urbanismo & 3 & 2 \\
Meio Ambiente & 2 & 20 \\
Energia & - & - \\
Tecnologia e Inovação & 4 & 3 \\
Saúde & 34 & 33 \\
Segurança & - & 44 \\
Educação & 1 & 5 \\
Empreendedorismo & 3 & 2 \\
Governança & 3 & 1 \\
Economia & 11 & 9 \\
\hline
\end{tabular}

Fonte: Adaptado de Urban Systems (2018).

Curitiba em 2017 ocupava o quarto lugar em mobilidade e acessibilidade, vindo a cair para a sétima posição em 2018. Outra queda refere-se ao meio ambiente, onde saiu do segundo lugar para o vigésimo. Obteve crescimento positivo de apenas um ponto quanto ao urbanismo (de terceiro para o segundo lugar), em tecnologia e inovação (de quarto para o terceiro lugar), em saúde (de 34 para 33) e empreendedorismo (do terceiro para o segundo lugar). Cresceu em segurança, onde saltou para o $44^{\circ}$ lugar, além de ter ganho dois pontos em governança (do terceiro para o primeiro) e em economia (do $11^{\circ}$ para o $9^{\circ}$ lugar).

Observando a Tabela 2 verifica-se que São Luís, entre 2017 e 2018, também obteve ganho expressivo em sua classificação no ranking.

Tabela 2. Classificação da cidade de São Luís, em 2017 e 2018.

\begin{tabular}{lcc}
\hline & São Luís & \\
\hline Posição & 2017 & 2018 \\
Connected Smart Cities & - & - \\
Mobilidade e Acessibilidade & - & - \\
Urbanismo & - & - \\
Meio Ambiente & - & - \\
Energia & - & - \\
Tecnologia e Inovação & 38 & - \\
Saúde & - & - \\
Segurança & - & - \\
Educação & - & - \\
Empreendedorismo & 11 & 43 \\
Governança & - & 32 \\
Economia & - & - \\
\hline
\end{tabular}

Fonte: Adaptado de Urban Systems (2017 e 2018). 
Seus maiores ganhos dizem respeito governança ( $32^{\circ}$ lugar no ranking). Houve perdas expressivas em outros eixos, como tecnologia e inovação $\left(38^{\circ}\right)$ e em empreendedorismo ( $11^{\circ}$ para $43^{\circ}$ lugar).

Entretanto, ao se comparar Curitiba e São Luís percebe-se, neste período, que São Luís evoluiu bastante em governança (Tabela 3).

Tabela 3. Comparação entre as cidades de Curitiba e de São Luís, em 2017 e 2018.

\begin{tabular}{lcccc} 
& \multicolumn{2}{c}{2017} & \multicolumn{2}{c}{2018} \\
\hline Posição & Curitiba & São Luís & Curitiba & São Luís \\
Connected Smart Cities & 2 & - & 1 & - \\
Mobilidade e Acessibilidade & 4 & - & 7 & - \\
Urbanismo & 3 & - & 2 & - \\
Meio Ambiente & 2 & - & 20 & - \\
Energia & - & - & - & - \\
Tecnologia e Inovação & 4 & 38 & 3 & - \\
Saúde & 34 & - & 33 & - \\
Segurança & - & - & 44 & - \\
Educação & 1 & - & 5 & - \\
Empreendedorismo & 3 & 11 & 2 & 43 \\
Governança & 3 & - & 1 & 32 \\
Economia & 11 & - & 9 & - \\
\hline
\end{tabular}

Fonte: Adaptado de Urban Systems (2017 e 2018).

\subsection{Proposta de soluções e de plano de ação prioritário para São Luís}

Considerando-se as prioridades para transformar São Luís em uma CIS, o plano de ação deve englobar propostas de soluções. Independentemente de sua aplicação, o plano de ação envolve projetos, tecnologias e pessoas.

É possível melhorar o desempenho de São Luís no Ranking Connected Smart Cities, que analisa apenas cidades brasileiras, com vistas à mobilidade, urbanismo, meio ambiente, energia, tecnologia e inovação, economia, educação, saúde, segurança, empreendedorismo e governança, visando melhor qualidade de vida e sustentabilidade, entre outros aspectos.

\subsubsection{Mobilidade urbana}

Vias de transporte adequadas, com ruas demarcadas com antecedência à construção de conjuntos habitacionais facilitaria o escoamento do trânsito, com quarteirões menores. Na Figura 4, observa-se a ligação da Avenida General Arthur Carvalho com outros bairros, onde nota-se grandes quarteirões, sem retornos.

Figura 4. Avenida General Arthur Carvalho.

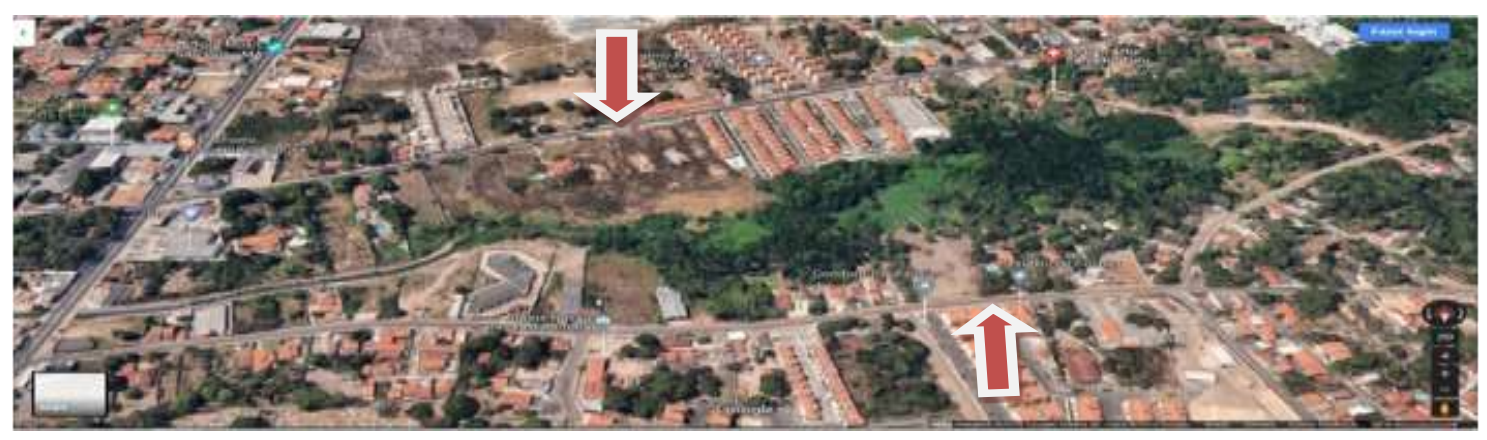

Fonte: Adaptado de Google Maps (2020). 
Research, Society and Development, v. 10, n. 4, e47810414166, 2021

(CC BY 4.0) | ISSN 2525-3409 | DOI: http://dx.doi.org/10.33448/rsd-v10i4.14166

Investir no alargamento de vias, interligação de bairros e conjuntos com a criação de pontes sobre riachos, também é necessário. A Figura 5 mostra a única ponte que interliga o bairro Parque dos Nobres à cidade.

Figura 5. Ponte que interliga o bairro Parque dos Nobres à cidade.

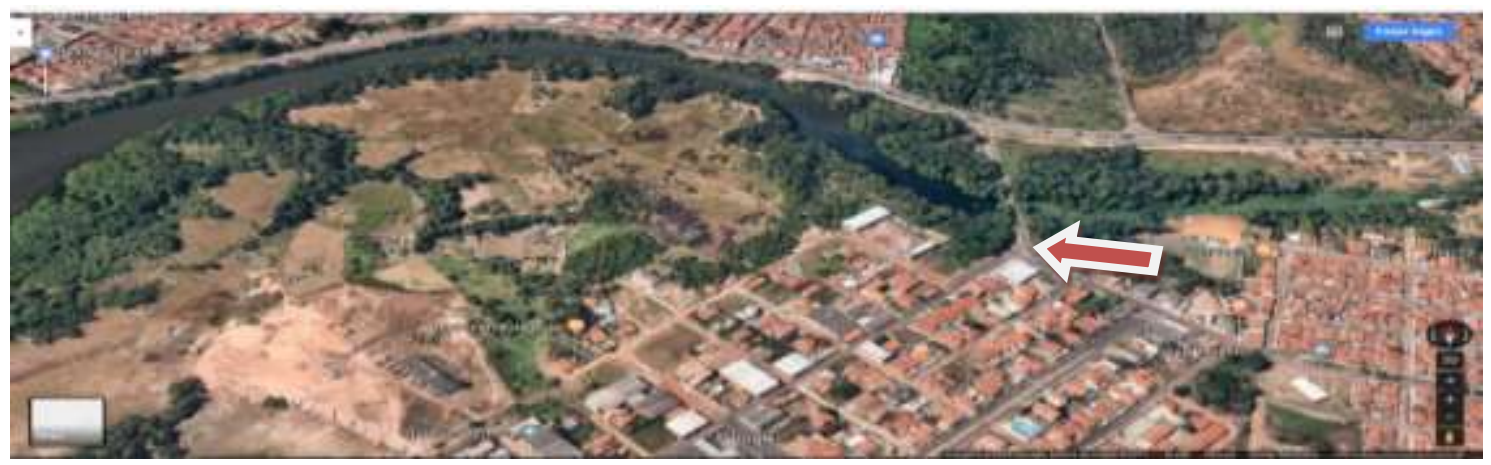

Fonte: Adaptado de Google Maps (2020).

Abertura de novas passagens entre conjuntos habitacionais (Figura 6), como a Ponte conhecida por Pai Inácio. Esta, por sua vez, deixa a desejar pela largura da passagem da ponte, estreitando duas pistas para uma única e voltando a ter duas pistas a menos de 50 metros depois.

Figura 6. Interligação entre os bairros Turu e Parque Vitória (Ponte Pai Inácio).

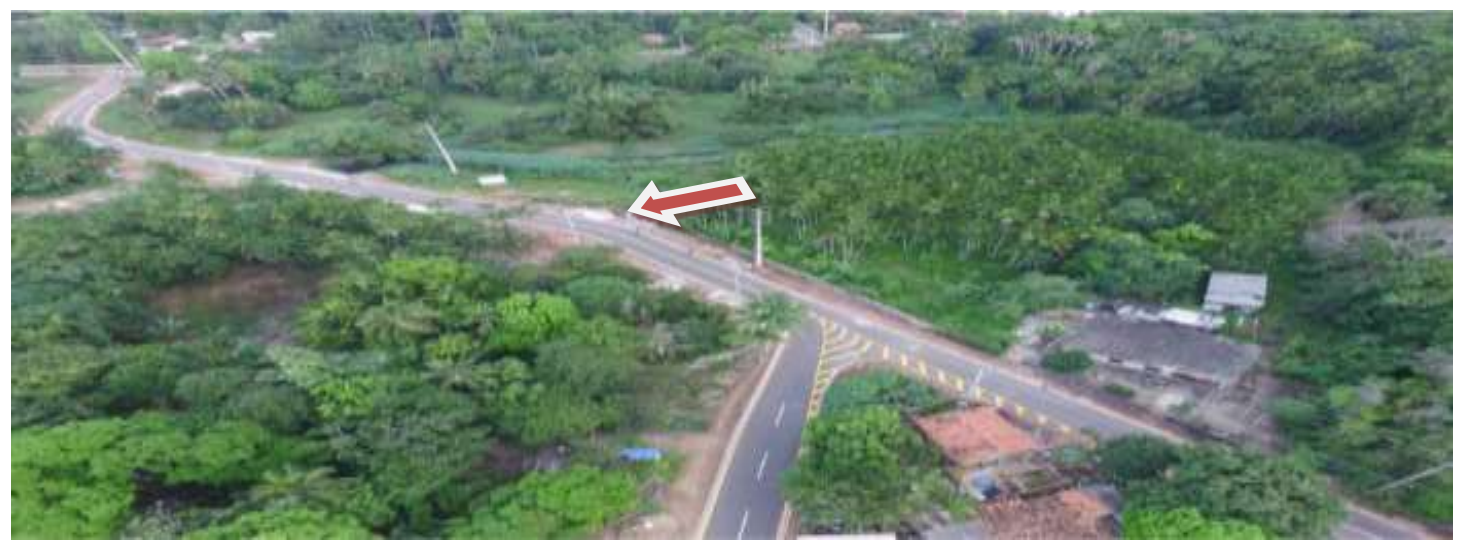

Fonte: Adaptado de Google Maps (2020).

O planejamento deveria incluir a manutenção das faixas de rolamento que, quando são pintadas, acabam sumindo da pista, transformando três vias em duas, repentinamente, como ocorre na mais extensa avenida, a Av. Jerônimo de Albuquerque, mostrado na Figura 7.

Figura 7. Avenida Jerônimo de Albuquerque onde 3 faixas, viram 2.

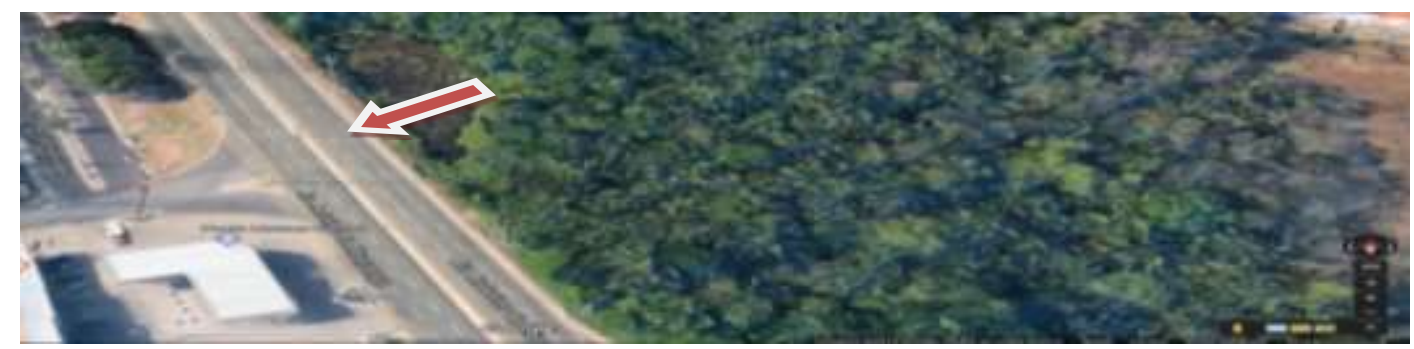

Fonte: Adaptado de Google Maps (2020). 
Ainda neste item, seria necessário a construção e manutenção das ciclovias, especialmente nos trajetos de maior mobilidade populacional. De acordo com o Diário de Sorocaba (2015), o custo da construção de $1 \mathrm{~km}$ de ciclovia é de cerca de $\mathrm{R} \$ 120$ mil reais, sendo considerados neste valor itens como o concreto com largura de 2,50 metros, pintura vermelha, sinalização horizontal, as bordas brancas e vertical, as placas, drenagem eventual, paisagismo e mão de obra envolvida nesses itens (Figura 8).

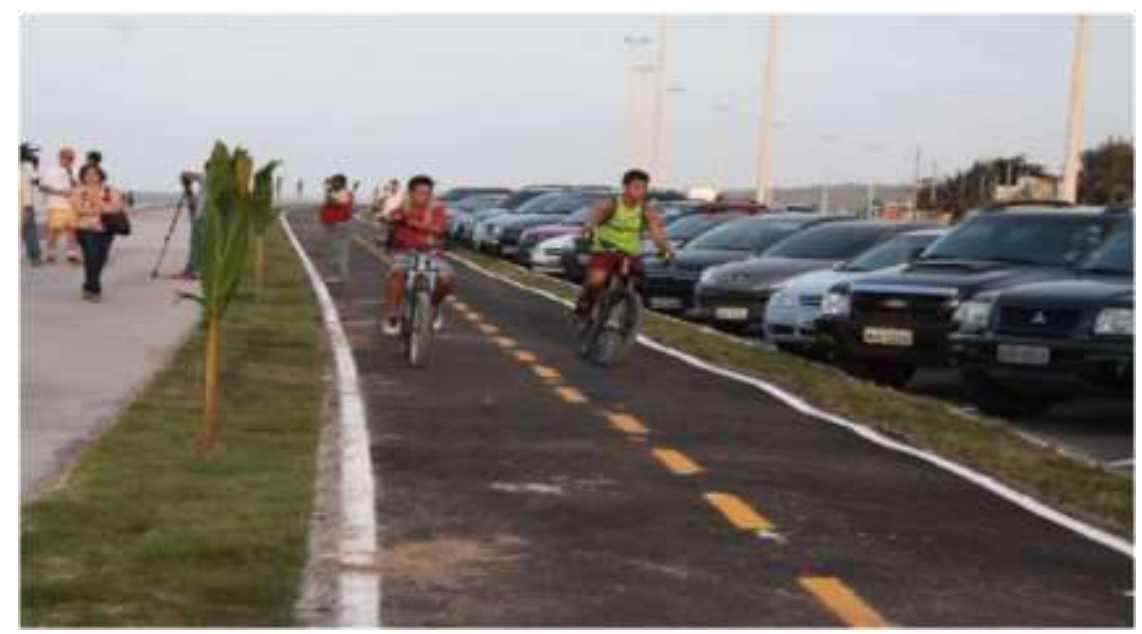

Figura 8. Ciclovia na Avenida Litorânea, em São Luís.

Fonte: Portal Guara (2019).

Considerando o valor corrigido pelo IPCA (BCB, 2020), com acúmulo de aproximadamente 26\% de 04/2015 a 12/2019, o custo médio hoje, por km é equivalente a R \$ 151.457,05. Ou seja, o custo da obra na cidade de São Luís para a extensão prevista de mais $110 \mathrm{~km}$ de ciclovias seria de aproximadamente R $\$ 16.660 .275,50$. Os custos da implantação da iluminação não foram computados na estimativa.

Além da mobilidade terrestre, através de convênios com o governo federal e estadual, poderia haver maior incremento quanto à mobilidade interestadual e intermunicipal, facilitando o acesso para pessoas que buscam realização de negócios, turismo, empreendimentos ou outras atividades na capital maranhense. Utilizando-se do poder conferido pelo Estatuto da Cidade (Brasil, 2001) de criar condições adequadas para o transporte de pessoas, seria necessária a aplicação da capacidade de desapropriar, visando a adequação das vias públicas, visto que algumas possuem três faixas de rolagem e repentinamente se transforma em uma única faixa, gerando engarrafamentos no trânsito e provocando acidentes entre pedestres e veículos; a limpeza de ruas e uniformização de calçadas, removendo-se as barreiras nela encontradas (mato, buracos, desníveis, coletores de águas pluviais inadequados ou inexistentes).

Maior integração entre os meios de transporte público utilizados, com maior opção além de ônibus e micro-ônibus, com a criação de linhas de trens interbairros, é outro ponto importante a ser realizado. Diminuição do tempo entre os ônibus que trafegam na cidade para cada bairro. Implantação de semáforos inteligentes, capazes de orientar melhor o trânsito, com sinal verde por mais tempo nas ruas e avenidas de maior fluxo, aumentar o número de ciclovias e fazer a manutenção correta das que existem, são sugestões de melhoria.

Implantação de um aplicativo gratuito, que ligue a diferentes opções de mobilidade para os passageiros personalizarem suas viagens e criação de um sistema de cartão inteligente de transporte público, que calcule automaticamente taxas para qualquer meio de locomoção viria a facilitar a mobilidade urbana. 
São Luís poderia realizar parcerias com o governo do Estado e governo Federal para incrementar o Aeroporto Internacional Marechal Cunha Machado, dando melhores condições para a trafegabilidade de voos em rotas internacionais, principalmente por estar mais próximo de regiões como a Europa e América Central, do que outras partes do país.

São Luís também poderia criar o seu crossrail (ligação ferroviária), através de parceria, para construir novas e importantes ligações ferroviárias, aproveitando as linhas férreas da Vale para realizar paradas de transporte de pessoas em determinados pontos da cidade.

Por se tratar de uma ilha, a única saída, excetuando mar e ar, é a ponte Marcelino Machado, conhecida por ponte do Estreito dos Mosquitos, inaugurada em 1970 e duplicada no ano 2006, sendo que necessita de manutenção permanente. Assim, através de parcerias da municipalidade com o governo do Estado e governo Federal, a construção de novas conexões entre a ilha e o continente facilitaria o escoamento da produção do interior para o porto do Itaqui, considerado a melhor rota marítima do Brasil para a Europa e demais países do leste, facilitando a exportação de produtos e insumos nacionais. Uma ponte entre a Ponta da Espera e o Cujupe (Alcântara-MA) facilitaria o acesso de turistas às áreas de Patrimônio Histórico de ambas cidades, bem como de trabalhadores e equipamentos ao Centro de Lançamento de Alcântara (CLA), uma das bases de lançamento de foguetes e satélites mais bem localizadas do mundo, melhorando o desenvolvimento da região e do país.

É possível melhorar em 10\% os tempos de viagem, a partir da implantação de sensores e câmeras capazes de fornecer estatísticas e modificar os padrões dos semáforos em uma ampla região, o que pode ser viável nas principais avenidas de São Luís, a partir do interesse público. Pontos de ônibus iluminados ou com teto espelhado para facilitar a claridade no local e ser de fácil visualização, a exemplo de São Paulo (Figura 9), placas de sinalização do destino do transporte em cada parada de ônibus, higienização dos veículos utilizados para o transporte coletivo, capacitação de condutores de veículos quanto às normas e ética, política de valorização profissional dos trabalhadores na área, fiscalização adequada quanto aos aspectos mencionados, manutenção das vias de transporte com operação tapa-buraco constante, são algumas das possibilidades de melhorar a mobilidade, propiciando qualidade de vida.

Figura 9. Ponto de ônibus com teto espelhado facilita visualização.

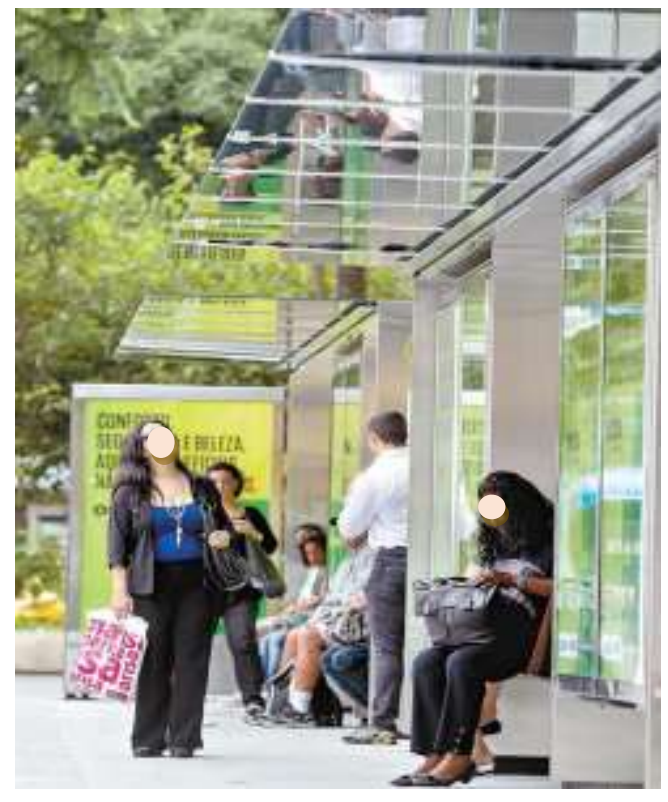

Fonte: Tecmundo (2013). 


\subsubsection{Meio ambiente}

É possível a implantação de uma plataforma que ofereça suporte e incentivo para cidadãos, instituições e empresas desenvolverem projetos verdes, pela municipalidade, não apenas incentivando empresas ao desenvolvimento de áreas verdes, bem como sua manutenção, considerando que parques e praças não conseguem ser mantidas limpas e organizadas o tempo todo, na cidade. É viável a utilização de materiais de construção adequados ao meio ambiente, bem como o incentivo à construção de novos parques e áreas verdes.

Os códigos e leis municipais, bem como as normas técnicas de edificações, também podem mitigar os impactos ambientais, por meio de diretrizes de projeto arquitetônico, uso de materiais e revestimentos apropriados, assim como de sistemas e subsistemas construtivos mais eficientes do ponto de vista energético, térmico e acústico. Desta forma, um plano diretor voltado não só ao planejamento estratégico, como ao meio ambiente, utilizando incentivo à construção de parques é uma solução, e novas vias urbanas em consonância com o meio ao redor também podem mitigar os efeitos do trânsito, quanto ao impacto ambiental.

\subsubsection{Saúde}

A saúde, propriamente dita, engloba uma série de fatores, que contemplam o completo bem-estar físico, mental e social. A taxa de mortalidade infantil é um indicador importante que revela não apenas as condições de saúde da população, mas também aspectos sociais, culturais e do sistema de saúde. Cuidados como pré-natal, parto, puerpério e vacinação antes mesmo de sair da maternidade respeitando o calendário vacinal, campanhas de educação em saúde junto à população, treinamento de funcionários para o correto acolhimento em saúde e demais funções facilitariam a qualidade do atendimento em saúde.

Parcerias com as universidades (que possuem cursos na área de saúde), melhor gestão e distribuição territorial das Unidades Básicas de Saúde, maior oferta de especialidades nos centros de atendimento em saúde, implantação de marcação de consulta on-line, implantação de mais hospitais e pronto socorros, além de parcerias com o governo do Estado para que os pacientes oriundos do Interior possam ser atendidos na localidade em que residem diminuindo o quantitativo de atendimentos na Capital, são alguns dos itens que podem e devem ser melhorados.

\subsubsection{Tecnologia e inovação}

São Luís é sede de várias Instituições de Ensino Superior, entre as quais Universidade Federal do Maranhão (UFMA), Instituto Federal do Maranhão (IFMA) e Universidade Estadual do Maranhão (UEMA), que poderiam receber incentivos para o desenvolvimento inicial. A capital maranhense poderia possuir uma plataforma de dados aberta utilizada por empresas, pesquisadores e desenvolvedores, com parcerias entre as universidades e o município, gerando não apenas conhecimento, mas mão de obra e emprego.

Ainda em relação à tecnologia aliada ao conhecimento, poderia haver oferta ao público de serviço gratuito de Wi-Fi, com o incentivo de empresas e/ou governo. É possível ainda, a exemplo de Nova York, ofertar acesso à internet para todos os residentes, incluindo teclado em braile, reunindo também informações sobre eventos locais, notícias de vizinhança, listas de entretenimento e alertas de segurança.

\subsubsection{Segurança}

Assim como Curitiba e outras cidades brasileiras, implantar um sistema de segurança que vá além do poder de polícia é fundamental, incluindo cuidados quanto a desastres ambientais, mobilidade, saúde e desastres em massa. Curitiba, por 
exemplo, conta com um centro de monitoramento de segurança pública e um centro de informações estratégicas e, a exemplo desta cidade, investimentos na infraestrutura tecnológica facilitariam a questão da segurança em São Luís, com a integração de informações entre as polícias, meteorologia, serviços de saúde, secretarias de meio ambiente e cidadãos.

\subsection{Plano de ação}

Primeiro, é necessário verificar quais os focos a serem trabalhados no Plano de Ação Prioritário, e em seguida definirem-se as linhas estratégicas de ação para concretizar a melhoria da cidade de São Luís. A partir dessas linhas estratégicas podem ser traçadas diretrizes e ações concretas, com a classificação da sua natureza, previsão dos custos de préinvestimento e investimento e prazos para sua execução.

Os temas prioritários para São Luís melhorar sua posição entre as CIS foram consolidados em três linhas estratégicas para organizar as intervenções propostas:

a) Gestão da administração pública, visando oferecer ao município os instrumentos de gestão necessários à promoção e à continuidade da CIS, e inclui aumento da eficiência e de uso de tecnologias, aspectos organizacionais da gestão, dimensões fiscais de arrecadação, visando melhoria contínua;

b) Gestão do saneamento básico em sentido amplo;

c) Adequação do uso do território e as relações entre o ambiente natural e o construído, bem como suas interferências sobre a mobilidade no município.

Além, destas três linhas estratégicas, é necessário incluir também o tema transversal de gestão energética, como forma de incentivo à geração de emprego e renda, diminuição de gastos públicos municipais (iluminação pública, energia gasta nas áreas de saúde e educação), aliado à aplicação de práticas sustentáveis e saneamento ambiental.

\subsubsection{Gestão da administração pública}

Quanto à gestão da administração pública, a principal prioridade seria a implantação de tecnologia de comunicação, com a possibilidade de financiamento pelo BID para a área tecnológica, proposto em 2016.

Do ponto de vista tecnológico baseado no desenvolvimento proposto pelo BID (2016), esta etapa do plano de ação envolve:

i. Infraestrutura de conectividade: implantação de banda-larga de internet, para receber e enviar dados; expandindo as que já se encontram instaladas;

ii. Instalação e conexão de sensores e dispositivos, captando sinais do meio ambiente para a rede de computadores dos centros de controle e gestão das cidades, integrando áreas como trânsito, segurança, alertas de emergência e de desastres naturais; expandindo os que já se encontram instalados;

iii. Criação de centros integrados de operação e controle, com computadores e softwares, capazes de captar, analisar e distribuir as informações para os demais centros envolvidos no gerenciamento de cidades, e a população;

iv. Facilitação da expansão das interfaces de comunicação, facilitando a troca de informações entre pessoas, empresas e governo, facilitando o acesso a dados e serviços.

Considerando-se uma cidade de 1 milhão de habitantes, prioritariamente deveria haver a implantação de $1.200 \mathrm{~km}$ de fibra ótica, para conectar ao centro de controle de cidades, os sensores, câmeras e entidades públicas do município (Estimativa baseada no BID, 2016). Nas Figuras 10 a-c, pode-se observar a esquematização das necessidades e viabilidades para a área, em São Luís. 
Figura 10. Esquema das necessidades para São Luís (a) Fibra ótica para rede troncal (b) Conexão para cabo ótico (c) Conexão telefônica.

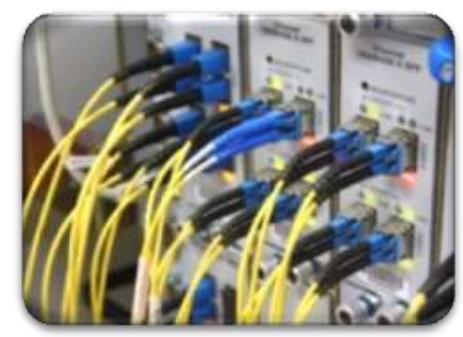

(a)

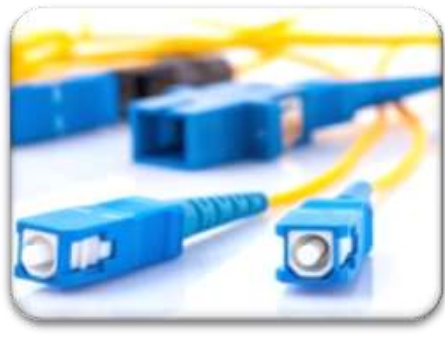

(b)

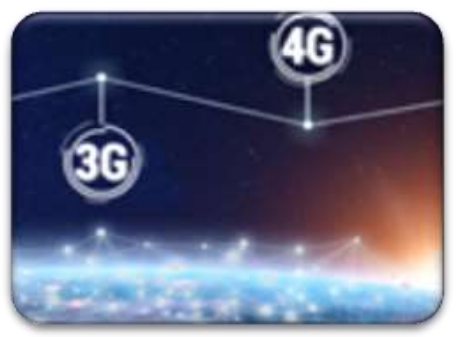

(c)

Fonte: Adaptado de Bouskela et al. (2016).

A Figura 10a mostra um possível esquema de conexões de $100 \mathrm{Km}$ de fibra ótica para a rede troncal com 1,5 Gbps para as 400 câmeras (-3,75 Mbps/câmera); 4,5 Gbps de amplitude de banda e 3,0 Gbps para as entidades públicas (10Mbps/local). Na Figura 10b, observa se a conexão de cabos óticos para possível integração da rede municipal em edifícios municipais e praças públicas, com velocidade média por fibra de $100 \mathrm{Mbps}$, para pontos de videomonitoramento, controladores de sinais de trânsito, quadro de mensagens variáveis, sirenes, barreiras eletrônicas, sensores de velocidade e sistema de estacionamento rotativo. A conexão telefônica $3 \mathrm{G}$ e $4 \mathrm{G}$ para motorização de veículos públicos câmeras e sensores está representada na Figura 10c.

Haverá a necessidade de conectividade para sensores e câmeras, centro integrado para receber dados de pontos externos e retransmiti-los, conectividade interna no centro para proteger acesso aos dados e a informação, e centro de contato (telefonia IP de 10 posições de operação para receber e administrar demandas, e 10 de atenção).

Serão necessários 400 câmeras de monitoramento, 140 para segurança e vigilância públicas locais, 100 em edifícios municipais (prefeitura, escolas, hospitais e etc.), 100 para transito (monitoramento, radar de velocidade, portais com leitura de placas), 60 câmeras de corpo para policiais e fiscais (3 câmeras cada um).

Haverá a necessidade de 20 botões de emergência e segurança, 20 totens de informação (serviços aos cidadãos), 20 sensores para observação com foco no meio ambiente e áreas de risco, 100 localizadores por GPS usando 3G/4G para monitoramento de veículos públicos e 50 sensores com diferentes funcionalidades.

Com os conhecimentos adquiridos com a iniciativa Cidades Emergentes e Sustentáveis é possível estimar que, para uma cidade de supostamente 250.000 a 500.000 habitantes, com densidade média de 46 habitantes por hectare e uma área de $162 \mathrm{~km}^{2}$, os custos de um projeto de Smart City estão aproximadamente entre US\$20 milhões e US $\$ 30$ milhões. No valor estimado, inclui-se a implementação de uma infraestrutura baseada em uma rede troncal de $600 \mathrm{~km}$ de fibra ótica, que conecta a 100 instituições. Prevê a instalação de sensores, câmeras e computadores, o desenvolvimento de aplicações dedicadas, a configuração de um Centro Integrado de Operação e Controle e de uma base de dados, e a formação de funcionários públicos e consultorias.

Pode-se iniciar um projeto piloto com um orçamento de entre US\$7 milhões e US $\$ 10$ milhões de dólares. A estimativa depende da infraestrutura já existente no município, a quantidade de equipes e instituições que serão conectadas, impostos e encargos sociais, assim como os gastos de operação e mantimento que afetam os valores de investimento. A Figura 11 mostra a descrição de cada etapa do fluxograma de controle, baseado nas informações do ranking elaborado pela Smart cities. 
Figura 11. Fluxograma de funcionamento das conexões de tecnologia de comunicação, e sua interação com diversas áreas.

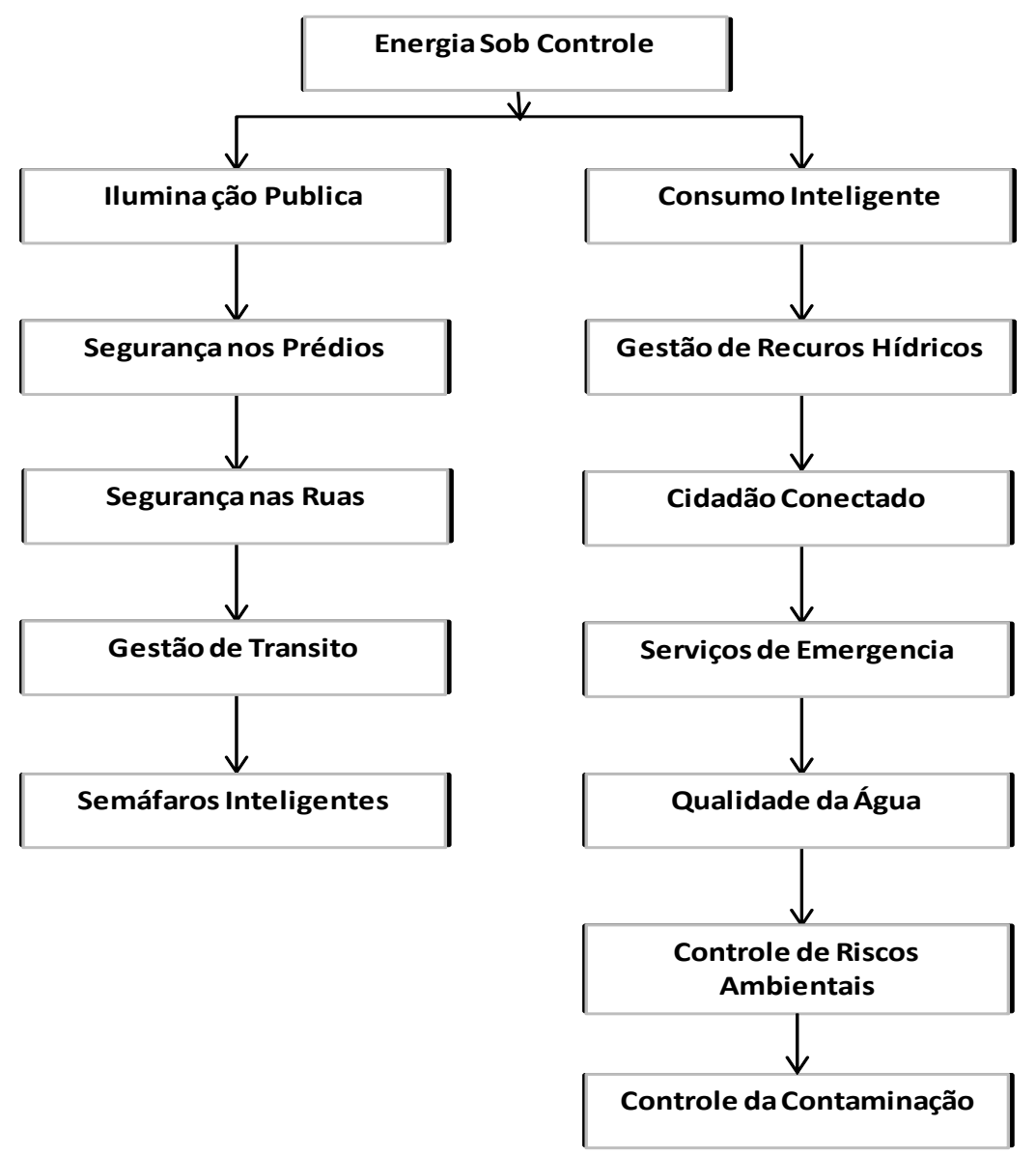

Fonte: Adaptado de Bouskela et al. (2016).

Energia sob controle, instalação de sensores na rede elétrica doméstica, associados a recursos de rede elétrica inteligente, permitem que o cidadão acompanhe a energia em casa e economize. Iluminação pública, sensores inteligentes nos postes de iluminação acendem e apagam automaticamente as lâmpadas de acordo com a luz do ambiente e movimento de pedestres. Segurança nos prédios, as câmeras de monitoramento dos entornos e os sensores de movimento e temperatura instalados nas portas e janelas vigiam remotamente e evitam riscos e danos. Segurança nas ruas, os sensores de movimento na rua associados as câmeras nos cruzamentos monitoram o trânsito e a segurança urbana. Gestão de trânsito, câmeras instaladas nos cruzamentos e semáforos associadas a sensores de movimento instalados nas ruas, permitem controlar e conduzir melhor o tráfego. Semáforos inteligentes, os semáforos controlados remotamente permitem alterar o tempo de fechamento e abertura de acordo com o fluxo de carros, evitando congestionamentos (Figura 11).

Consumo inteligente, Sistemas digitais inteligentes nas residências permitem que o cidadão faça o acompanhamento de consumo individual de água e controle. Gestão de recurso hídrico, os sensores de pressão de água nos tubos monitoram o fluxo de água e identificam eventuais fugas na rede da cidade. Cidadão conectado, com o uso de aplicações móveis e telefones inteligentes com câmera, os cidadãos podem receber alertas e informações úteis, assim como enviar dados contribuindo com a gestão. Serviços de emergência, os dispositivos de GPS nos veículos de emergência permitem localizá-los e utilizando câmeras e semáforos inteligentes, dirigi-los as melhores rotas. Qualidade da água, com o uso dos sensores também é possível acompanhar os níveis dos rios, das praias, dos reservatórios e a qualidade da água. Controle de riscos ambientais, sensores instalados nas fábricas e no ambiente permitem monitorar a qualidade do ar (contaminação do ambiente e nível de CO2) e 
fugas químicas na água. Controle da contaminação, os sensores de fumaça, gases tóxicos e temperatura, associados a câmeras de monitoramento do entorno e sistema de alerta evitam desastres (Figura 11).

\subsubsection{Gestão do saneamento}

Quanto à gestão do saneamento, a principal prioridade seria o saneamento básico, considerando-se o conjunto que inclui abastecimento de água potável, esgotamento sanitário, drenagem e manejo das águas pluviais urbanas, limpeza urbana e manejo dos resíduos sólidos.

As principais diretrizes para a realização desta tarefa dizem respeito aos seguintes tópicos:

a) Criar o sistema municipal de informações sobre saneamento básico, com a finalidade de implantar banco de dados, compartilhando informações em parceria com o governo do Estado, consolidando modelo amplo de gestão dos serviços, contendo informações e indicadores necessários à formulação, ao monitoramento e à avaliação das políticas públicas do setor, e facilitando intervenções e ações na rede, quando necessárias;

b) Em parceria com o governo do Estado, diminuir as perdas do sistema de abastecimento, quer seja por meio de uso de sensores que podem ser implantados na primeira etapa deste plano de ação, ou outros métodos, que inclui a capacitação dos técnicos para verificação "in loco" das necessidades de manutenção da rede; implantação de macromedidores nos pontos de produção, adução e distribuição, substituição de hidrômetros (antigos ou com problemas) e eliminação de vazamentos.

A estimativa geral de custo da implementação da ação é de $\mathrm{R} \$ 32.800 .000,00$ (com base na estimativa realizada pelo IBAN, 2015, para a cidade de Florianópolis, com população estimada de 500 mil habitantes em 2019, segundo o IBGE).

Melhorar o atendimento do sistema de abastecimento de água, em parceria com o governo do Estado, para atingir cobertura total da população, implantando pontos de estação de tratamento de água (ETA), a ser realizado com financiamento do Ministério das Cidades/CAIXA. Custo estimado de cada ETA, R\$ 14 milhões (com base na estimativa realizada pelo IBAN, 2015, para a cidade de Florianópolis).

Ampliar a rede de esgoto e implantar estações de tratamento de esgoto (ETE) ao longo da rede, com reaproveitamento dos resíduos sólidos (bloquetes para calçadas, por exemplo). Custo estimado de $\mathrm{R} \$ 221.200 .000,00$ (com base na estimativa realizada pelo IBAN, 2015, para a cidade de Florianópolis).

Elaboração do plano diretor de drenagem e manejo das águas pluviais urbanas (gestão e manejo), visando evitar alagamentos, enchentes, deslizamento de encostas, doenças de veiculação hídrica.

Dotar São Luís (em parceria com os outros municípios da ilha) de instrumentos técnicos e institucionais, com medidas de controle estruturantes e não estruturantes. As primeiras dizem respeito à redução do risco de inundações (como a implantação de bocas de lobo nas sarjetas de ruas e avenidas, com esgotamento sanitário), enquanto que as medidas não estruturantes dizem respeito ao uso e ocupação do solo (plano de manutenção preventiva, controle de impermeabilização, projeto e manual de drenagem).

Ampliação e implantação da coleta seletiva de lixo residencial e industrial, para recuperar resíduos sólidos, com a construção de pontos de entrega voluntária de resíduos secos e orgânicos, e construção de local de triagem e seleção de resíduos, gerando emprego e renda, além de evitar o envio para lixões e aterros sanitários, ou descarte nas ruas, e de evitar gastos desnecessários com limpeza pública, desentupimento de bocas de lobo, doenças provocadas por vetores e gastos evitáveis em saúde. Financiamento: Ministério das Cidades, parcerias público/privadas.

Quanto ao financiamento dos custos de implantação destas melhorias, estes poderiam ser oriundos de parcerias público-privadas (Ministério das Cidades, Caixa, BID, outras instituições), compartilhamento de responsabilidades com os 
outros municípios que integram a ilha (São Luís, Raposa, São José De Ribamar, Paço Do Lumiar); ações colaborativas de grupos institucionais ou comunitários.

As consequências imediatas são melhora da saúde da população, menores gastos hospitalares; melhor atrativo para o turismo com consequente aumento de emprego e renda; melhor qualidade de vida.

\subsubsection{Adequação do uso do território}

A adequação do uso do solo e ordenamento territorial de São Luís reflete ainda a questão da mobilidade urbana, bem como cuidados quanto a vulnerabilidades a desastres naturais devido à mudança climática, e inclui não apenas o Plano Diretor da cidade, mas também a utilização dos instrumentos de gestão previstos no Estatuto da Cidade (Lei Federal no 10.257/2001) e no Estatuto da Metrópole (Lei Federal nº 13.089/2015).

Há necessidade de colocação em prática dos instrumentos que promovem a requalificação urbanística das áreas de expansão urbana e a valorização do uso do solo não urbano (Lei Municipal de Uso e Parcelamento do Solo, e Plano Diretor da cidade), evitando a ampliação constante do perímetro urbano e o parcelamento de glebas rurais, que viriam a aumentar o custo da aquisição dos imóveis, dificultando inclusive a mobilidade das pessoas no que tange à distância do local de trabalho.

Do ponto de vista da vulnerabilidade às mudanças do clima, há variadas ações a serem desenvolvidas, tais como esgotamento de águas pluviais, contenção de muros e encostas e outros temas relacionados às condições de uso do solo e ordenamento territorial.

Em relação à mobilidade, a aplicação de leis e planos preveem ações que devem ser firmadas. Assim, são necessárias à aplicação dos instrumentos de gestão da cidade previstos no Estatuto da Cidade (Lei Federal no 10.257/2001) e Estatuto da Metrópole (Lei Federal n ${ }^{\circ}$ 13.089/2015), e reafirmados no Plano Diretor, visando o equilíbrio de mobilidade/uso do solo.

Com a implantação das TICs prevista no tópico Gestão Pública é possível realizar o monitoramento e controle das redes de transportes e explorando a multimodalidade do município (integração com transporte alternativo, ubers, taxis).

As ações prioritárias são complementação e detalhamento do Plano Municipal de Mobilidade Urbana e Transportes. A complementação e detalhamento deve ser tratada como prioritária para viabilização das demais ações que tenham por objetivo a melhoria da mobilidade urbana, pois além de garantir recursos orçamentários federais, conforme preconiza a Lei $\mathrm{n}^{\circ}$ 12.587/2012, também traz segurança jurídica para as ações. A efetividade da complementação e do detalhamento depende do desenvolvimento de uma série de estudos que possibilitem a formulação e articulação das políticas de mobilidade para o município.

A conurbação e interdependência dos municípios que estão inseridos na ilha tem como efeito uma alta movimentação de veículos entre estes. Para minimizar, implantar alguns terminais de integração de ônibus (Figura 12) expandindo a linha já existente para os novos bairros que se formam, a exemplo do Araçagy, pertencente parte a Paço do Lumiar e parte à São José de Ribamar, mas que fazem parte da ilha, como se fora consequência do crescimento da cidade de São Luís. Tal panorama torna essencial que seja considerado na execução do plano de mobilidade do município.

Na Figura 12, é mostrado em vermelho a localização dos terminais de integração. 
Figura 12. Localização dos terminais de integração.

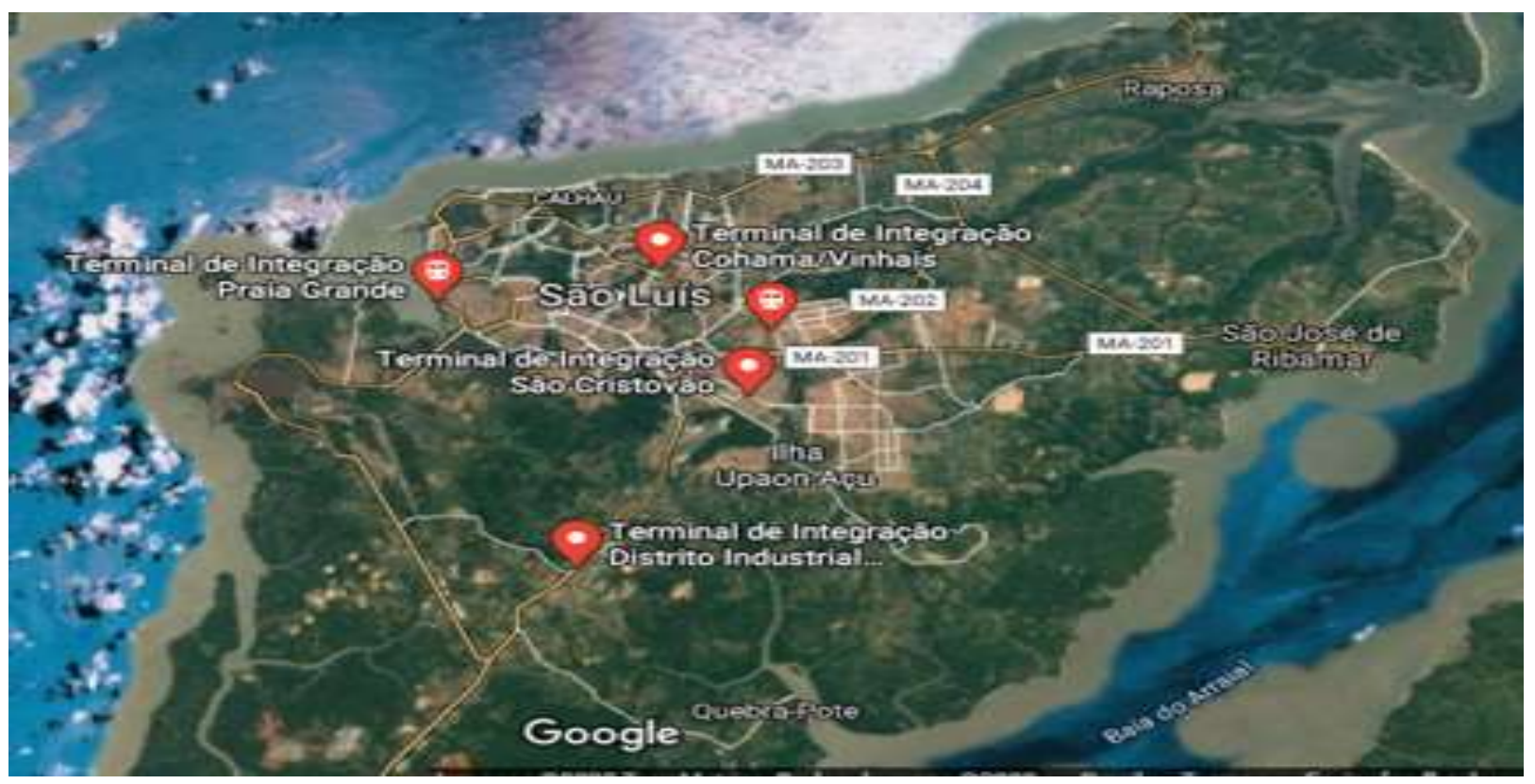

Fonte: Adaptado de Google Maps (2020).

Na Figura 13 tem se demarcado, em vermelho, a Avenida dos Holandeses, que muda seu nome em alguns trechos, interligando as cidades de São Luís, São José de Ribamar, Paço do Lumiar e Raposa, numa trajetória paralela às praias. Notase que, quando comparada à figura anterior, os terminais de integração estão totalmente deslocados em relação à trajetória desta avenida importante na capital maranhense.

Figura 13. Avenida dos Holandeses.

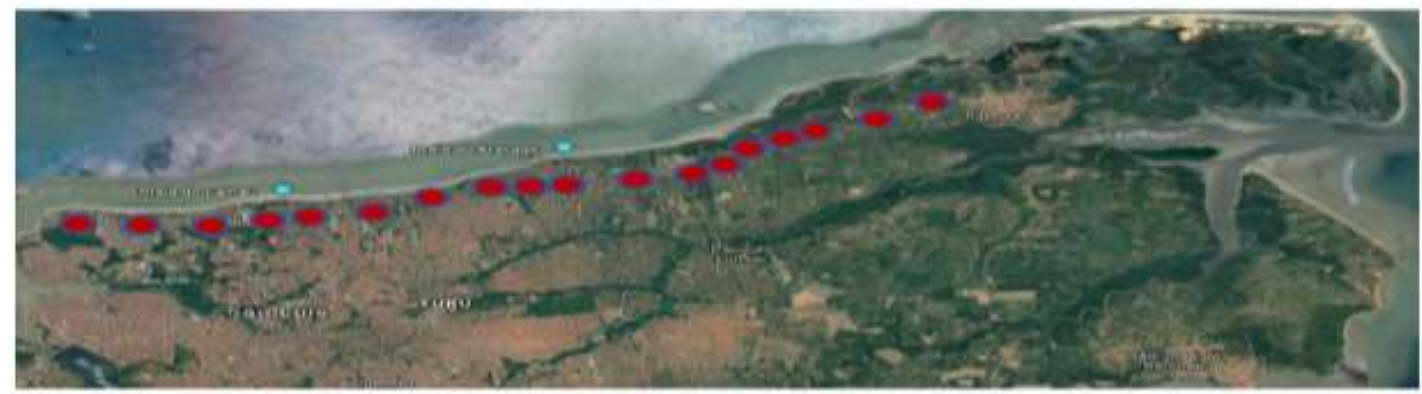

Fonte: Adaptado de Google Maps (2020).

Assim, para facilitar a mobilidade, são necessários: expansão da capacidade viária e gestão de tráfego; regulação de transporte de mercadorias, proibindo-os especialmente nos horários de pico; reestruturação do transporte coletivo integrado para a região metropolitana, incluindo todas as cidades que compõem a ilha; Implantação de pontos de integrações do transporte público ao privado, como transporte alternativo, Ubers e táxis.

Já, para facilitar a gestão, são necessários:

1. Dotar a administração pública de instrumentos capazes de monitorar e controlar o desempenho dos sistemas de transportes público e privado, a partir da implementação das TICs. Sugere-se a criação de um Centro de Controle Operacional de Transporte, para promover medidas preventivas e corretivas capazes de adaptar o plano de mobilidade às vicissitudes inerentes aos sistemas de transportes.

2. Melhorar a qualidade da infraestrutura para os transportes públicos, o qual compartilha das mesmas vias 
utilizadas para o transporte privado, com algumas exceções (Bairros do São Francisco e Renascença), onde foram implantadas faixas exclusivas para ônibus. Recuo de calçada e expansão da via nas paradas de ônibus também facilitaria o trânsito, desafogando-o, as calçadas devem ser priorizadas, como áreas para pedestres. O custo estimado de mão de obra e material para execução de calçada é de R \$40,00 por metro quadrado, segundo estimativa da Prefeitura de São Paulo, para o ano de 2015.

3. Implantação de corredores de BRT (Bus Rapid Transit), capazes de assegurar a regularidade e a confiabilidade do serviço, sendo possível determinar com considerável precisão a frequência com que os ônibus passam, reduzindo os custos financeiros e ambientais devido ao menor gasto de combustível e consequente diminuição das emissões de gases. Tais ações poderiam ser executadas com recursos financeiros previstos pelo Ministério das Cidades e Caixa.

4. Implantação do Sistema Inteligente de Monitoramento (SIM): este sistema visa melhorar o gerenciamento do transporte público e auxiliar o passageiro na decisão de escolha por qual meio irá se locomover. Fazem parte deste sistema a instalação de semáforos inteligentes no corredor do anel viário, de forma que permita aos semáforos priorizarem a passagem de veículos do transporte público ao identificar sua aproximação; a instalação de câmeras de fiscalização e um sistema de coleta de dados. Os recursos financeiros podem ser advindos do Ministério das Cidades/ Caixa.

5. Elaboração do plano de regularização urbanística, fazendo valer o Estatuto das Cidades e o Plano Diretor, a elaboração de um plano de regularização urbanística teria como primórdios a questão da qualidade de vida das pessoas. O Plano Diretor deverá prever fiscalização das áreas demarcadas como de proteção ambiental (Figuras 14 a 17), evitando o crescimento desordenado, prever ações de regularização dos loteamentos, determinando a largura de ruas e quadras, e a reserva de espaços públicos e prever a localização de áreas institucionais, além das áreas verdes. A Figura 14 mostra o Parque Estadual Sítio do Rangedor, localizado em São Luís, e cadastrado como área de proteção ambiental.

Figura 14. Parque Estadual Sítio do Rangedor - Área de Proteção Ambiental.

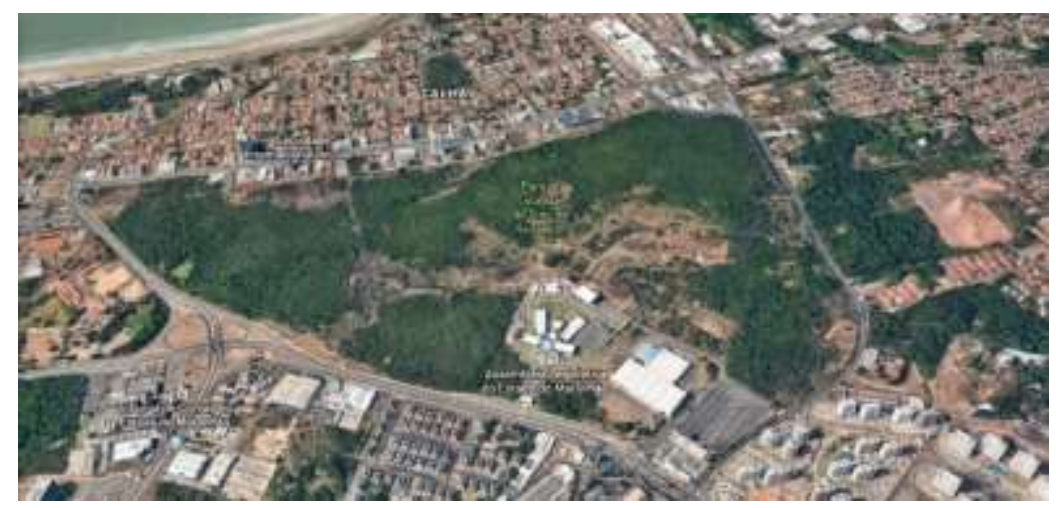

Fonte: Google Earth (2020).

A Figura 15 mostra a Reserva do Itapiracó, criada em1997, sendo esta uma outra área de proteção ambiental que está inserida nas cidades de São Luís e São José de Ribamar, que possuem limites de município. 
Research, Society and Development, v. 10, n. 4, e47810414166, 2021

(CC BY 4.0) | ISSN 2525-3409 | DOI: http://dx.doi.org/10.33448/rsd-v10i4.14166

Figura 15. Reserva do Itapiracó - Área de Proteção Ambiental.

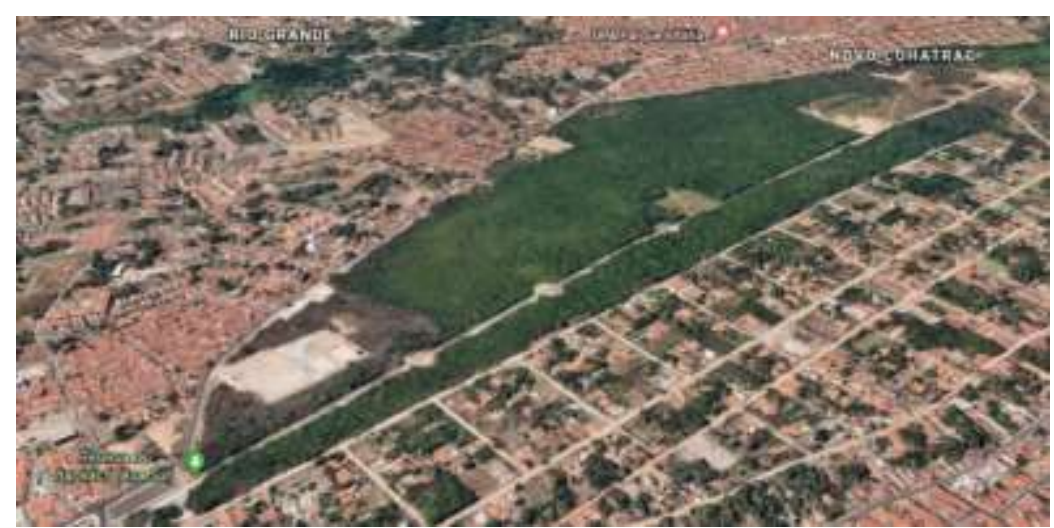

Fonte: Google Earth (2020).

A Figura 16 destaca a Reserva do Batatã, uma área de preservação permanente, onde há um dos principais reservatórios de água para a cidade.

Figura 16. Reserva do Batatã - Área de Proteção Ambiental.

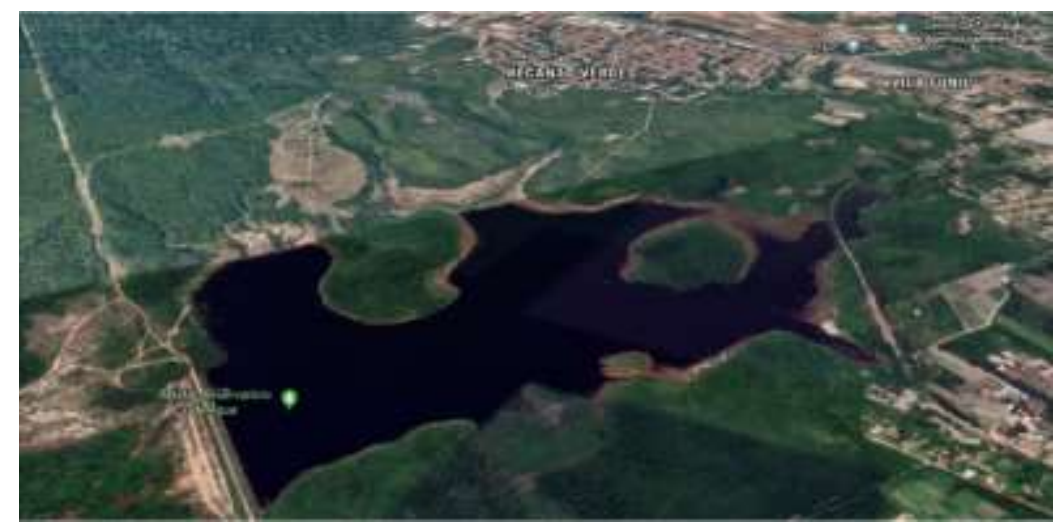

Fonte: Google Earth (2020).

Na Figura 17, pode ser visto o Parque Estadual do Bacanga, criado em 1980, com uma área de 3075 hectares, e onde a Reserva do Batatã (Figura 16) está inserida.

Figura 17. Parque Estadual do Bacanga - Área de Proteção Ambiental.

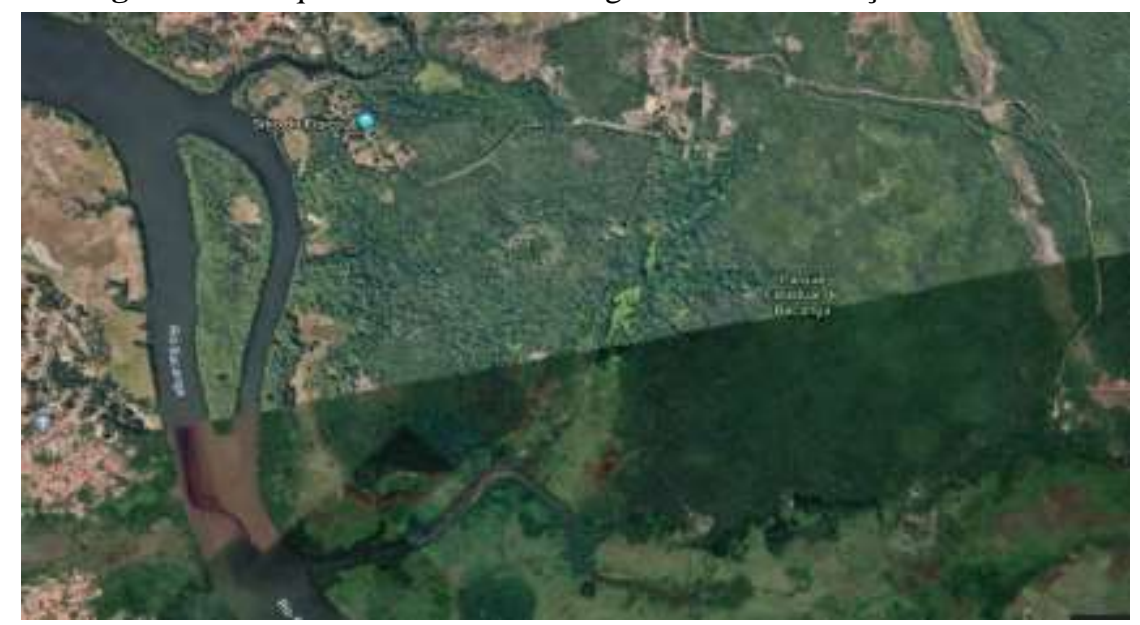

Fonte: Google Earth (2020). 
O setor de obras e engenharia da municipalidade possui técnicos e profissionais capazes de realizar o plano, sem custo adicional para a cidade. Colocá-lo em prática dependeria da eficiência do setor de fiscalização.

As cidades inteligentes e sustentáveis são fundamentadas no pleno direito social brasileiro, devendo as cidades se aprimorarem no sentido de mitigar, tratar e prevenir os problemas oriundos do crescimento populacional nas áreas urbanas, para atingirem a meta da sustentabilidade.

\section{Considerações Finais}

Os principais índices internacionais que medem e classificam as CIS possuem indicadores diferentes entre si, sendo que cidades podem estar em primeiro lugar num índice e podem se encontrar em outra posição nos demais. Para o ranking IESE Cities in Motion Index, 2017, a cidade de Nova York seria a mais inteligente do mundo naquele ano, enquanto que Curitiba apareceria em sétimo lugar. Já no índice da University of Navarra CIMI 2018, Londres é a cidade mais inteligente do planeta, seguido de Nova York, e onde Curitiba ocupa o $140^{\circ}$ lugar.

O Global Cities Index 2018, da A.T. Kearney, examina o desempenho e competitividade das cidades quanto aos aspectos atividade comercial, capital humano, intercâmbio de informações, experiência cultural e governabilidade. A A.T. Kearney também trabalha com outro índice, o Ranking Global Cities Outlook, onde são mensurados quatro itens: bem-estar social, economia, inovação e governabilidade, com seus subitens; e ao combinar ambos índices, a A.T. Kearney produz o Ranking The Global Elite, que aponta a classificação das cidades, mas não suas dimensões analisadas.

O Global Financial Centers Index realiza comparação sobre a competitividade dos principais centros financeiros do mundo e utiliza 133 fatores em sua mensuração.

Já o O Global Power City Index utiliza índices para avaliar e classificar as principais cidades de acordo com seu magnetismo ou seu poder abrangente para atrair pessoas, capital e empresas de todos os continentes, através da medição de seis funções divididas em 70 subdivisões, e onde, da América Latina, são citadas Buenos Aires, em $38^{\circ}$ lugar, e São Paulo, em $40^{\circ}$, do total de 44 cidades mundiais analisadas.

Por outro lado, o Quality of Living City Ranking 2018, avalia 450 cidades em todo o planeta, de acordo com 39 fatores, agrupados em dez categorias, sendo que o ranking de 2019 avaliou 231 cidades, onde Viena ocupa a posição de liderança pelo nono ano consecutivo, e quatro cidades brasileiras são citadas, sendo Brasília em $107^{\circ}$; Rio de Janeiro $\left(118^{\circ}\right)$, São Paulo $\left(119^{\circ}\right)$ e Manaus $\left(127^{\circ}\right)$.

O Global Liveability Index analisa 140 cidades do mundo, do ponto de vista qualitativo e quantitativo de cinco categorias (governança/estabilidade, saúde, cultura e meio ambiente, educação e infraestrutura) e seus subitens, e onde Viena é classificada como a cidade número um mais habitável do mundo, seguida de Melbourne.

O Sustanaible City Index analisa 100 cidades sob a perspectiva do cidadão, onde, da América Latina, na edição de

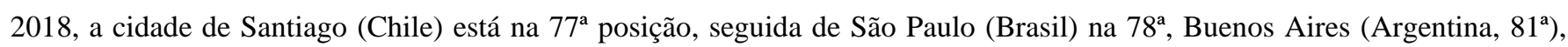
Rio de Janeiro (Brasil, 84ª), Lima (Peru, 85ª) e Salvador (Brasil, 86 ${ }^{\mathrm{a}}$ ).

Quando se comparam apenas cidades brasileiras, o Ranking Connected Smart Cities, usando 70 indicadores, é o mais indicado por se focar apenas no país, apontando como cidades mais inteligentes e conectadas do Brasil as capitais São Paulo, Curitiba, Rio de Janeiro, Belo Horizonte e Vitória, na lista divulgada em 2017, posição esta que se modificou-se em 2018, com a entrada de Florianópolis e Porto Alegre na lista.

É possível, através do uso de indicadores de rankings de cidades inteligentes e sustentáveis, encontrar soluções para problemas de engarrafamento no trânsito, melhorar o acesso aos serviços de saúde, melhorar a educação e outros fatores fundamentais para a garantia da sustentabilidade, além de proporcionar melhora da qualidade de vida e do meio ambiente através do planejamento adequado. 
Comparativamente a Curitiba, São Luís tem potencial para se transformar em cidade inteligente e sustentável. E um caminho para esta transformação pode ocorrer através de parcerias da municipalidade com os governos do estado e federal, e com parcerias com instituições privadas, visando melhoria em habitação, mobilidade, urbanismo, meio ambiente, saúde, educação, tecnologia e inovação, segurança, empreendedorismo e governança.

Quanto à São Luís, diagnóstico, priorização e elaboração de propostas de solução são viáveis, para que haja uma préinversão de sua situação e possível monitoramento, consolidando-se como cidade inteligente e sustentável.

O desenvolvimento e a colocação em prática de um plano de ação prioritário, como o proposto no presente trabalho é fundamental para iniciar o processo de transformação de São Luís numa CIS.

Devido à grande abrangência do assunto abordado neste estudo, os investigadores apontam algumas sugestões para a continuação deste trabalho: Realizar estudo específico sobre cada um dos indicadores utilizados por cada dos rankings; Criar um ranking único, com todos os indicadores dos principais rankings devidamente agrupados; Realizar estudos sobre as principais cidades do Brasil, a fim de indicar adequações para que se transformem em cidades inteligentes e sustentáveis; Aplicar o método da Urban Systems em análise comparativa entre as cidades brasileiras, indicando possíveis soluções para os problemas enfrentados.

\section{Agradecimentos}

Agradecemos à Universidade Federal do Pará pela contribuição e apoio no desenvolver deste trabalho de mestrado.

\section{Referências}

Alves, N. (2018). Smart City: as 7 cidades mais inteligentes do mundo. Construct. <https://constructapp.io/pt/smart-city-cidades-mais-inteligentes>.

Andrade, J. N., \& Galvão, D. C. (2016). O conceito de smart cities aliado à mobilidade urbana. REVISTA HUM@ NAE, 10(1).

ARCADIS (2018). Citizen Centric Cities. The Susteinable Cities Index 2018 - SCI. <https://www.arcadis.com/media/1/D/5/\%7B1D5AE7E2-A348-4B6EB1D7-6D94FA7D7567\%7DSustainable_Cities_Index_2018_Arcadis.pdf>.

Atlee, T. (2004). Definitions of Collective Intelligence.Wayback Machine. Blog of Collective Intelligence.

Benites, A. J. (2016). Análise das cidades inteligentes sob a perspectiva da sustentabilidade: o caso do Centro de Operações do Rio de Janeiro. Dissertação de Mestrado, Universidade Estadual de Campinas, Instituto de Geociências, Campinas, SP.

Berrone, P., Ricart, J. E., T-Figueras, A. I. D., Carrasco, C., Guiliodori, D. A., \& Guiliodori, M. A. (2019). IESE Cities in Motion Index 2019. Business School University of Navarra. < https://media.iese.edu/research/pdfs/ST-0509-E.pdf>.

Bouskela, M., Casseb, M., Bassi, S., De Luca, C., \& Facchina, M. (2016). La ruta hacia las smart cities: Migrando de una gestión tradicional a la ciudad inteligente (Vol. 454). Inter-American Development Bank. Brasil. Presidência da República. Casa Civil. Subchefia para assuntos jurídicos. Constituição da República Federativa do Brasil de 1988. <http://www.planalto.gov.br/ccivil_03/Constituicao/Constituicao.htm>.

Brasil. Presidência da República. Casa Civil. Subchefia para assuntos jurídicos. Lei 10.257, de 10 de julho de 2001 . Regulamenta os arts. 182 e 183 da Constituição Federal, estabelece diretrizes gerais da política urbana e dá outras providências. <http://www.planalto.gov.br/ccivil_03/leis/leis_2001/110257.htm>.

Brasil. Presidência da República. Casa Civil. Subchefia para assuntos jurídicos. Lei 13.089, de 12 de janeiro de 2015 . Institui o Estatuto da Metrópole, altera lei 10.257 de 10 de julho de 2001, e dá outras providências. < http://www.planalto.gov.br/ccivil_03/_ato2015-2018/2015/lei/113089.htm>.

C40 São Paulo Climate Summit (2011). Construindo Cidades sustentáveis: Síntese do C40 São Paulo Climate Summit 2011. Prefeitura de São Paulo, Secretaria Municipal de Desenvolvimento Urbano e Universidade de São Paulo. <https://cetesb.sp.gov.br/proclima/2014/05/13/construindo-cidadessustentaveis-sintese-do-c40-sao-paulo-climate-summit-2011/>.

Calegari, L (2017). As 100 cidades mais inteligentes (e conectadas) do Brasil. <https://exame.abril.com.br/brasil/as-100-cidades-mais-inteligentes-econectadas-do-brasil/>.

Caragliu, A., Del Bo, C., \& Nijkamp, P. (2011). Smart cities in Europe. Journal of urban technology, 18(2), 65-82.

Censi, D. R. (2009). Conflitos socioambientais urbano-metropolitanos: cidadania, sustentabilidade e gestão no contexto da RMC-Região Metropolitana de Curitiba. Tese de Doutorado, Universidade Federal do Paraná.

Cunha, M. B (2016). Mobilidade urbana sustentável: um comparativo das cidades de Porto Alegre e Curitiba. Trabalho de Conclusão de Curso, Departamento de Engenharia Civil, Escola de Engenharia, Universidade Federal do Rio Grande do Sul. 
Dameri, R. P., \& Cocchia, A. (2013). Smart city and digital city: twenty years of terminology evolution. X Conference of the Italian Chapter of AIS, ITAIS: 18 .

Diário de Sorocaba (2015). Cada metro de ciclovia custa cerca de \$120. <https://www.diariodesorocaba.com.br/noticia/233140>.

Duarte, C. M. R. (2007). Reflexos das políticas de saúde sobre as tendências da mortalidade infantil no Brasil: revisão da literatura sobre a última década. Cadernos de Saúde Pública, 23(7), 1511-1528.

Dullius, A., de Oliveira, E. R. X., da Silva, M. C., \& Sanquetta, C. R. (2017). Urban Sustainability By Analysis Of Renewable Technologies In The Public Transport Of The City Of Curitiba/Sustentabilidade Urbana Por Meio De Analise De Tecnologias Renovaveis No Transporte Publico Da Cidade De Curitiba/Sostenibilidad Urbana Por Medio De Analisis De Tecnologias Renovables En El Transporte Publico De La Ciudad De Curitiba. Revista de Gestão Ambiental e da Sustentabilidade, 6(2), 73-89.

Duran, J., \& Pérez, V. (2015). Smart, innovative and sustainable cities for the future income: Caracas city. In 2015 IEEE Thirty Fifth Central American and Panama Convention (CONCAPAN XXXV) (pp. 1-6). IEEE.

Faria, A. C., Amaral Russi, R., Marcato, A. F. G., \& Paschoalin Filho, J. A. (2017). Sustentabilidade urbana e o desenvolvimento da cidade de São Francisco (EUA). DRd-Desenvolvimento Regional em debate, 7(1), 214-235.

Florida, R (2002). The Rise of Creative Class: and how its transforming work, leisure, community and everyday life. Basic Books.

França, E., \& Lansky, S. (2016). Mortalidade infantil neonatal no Brasil: situação, tendências e perspectivas. Anais, 1-29.

Furtado, L (2017). 5 momentos sem urbanismo em São Luís. O Imparcial. <https://oimparcial.com.br/noticias/2017/11/5-momentos-sem-urbanismo-em-saoluis/>.

Google Earth. Parque Estadual do Bacanga. <https://earth.google.com/web/search/parque+estadual+do+bacanga/@-2.58541,-44.2773344,24.0515823 9a,1055.3386483d,35y,0h,45t,0r/data=CoQBGloSVAokMHg3ZjY4NTFjMWEwMWZiMGI6MHhiMzhlYTc2ZmRhMjMxYjVkGckCJnDrrgTAISQHkbF_I0 bAKhpwYXJxdWUgZXNOYWR1YWwgZG8gYmFjYW5nYRgCIAEiJgokCaTiqsROsgTAEQ5LPkk01QTAGXEE-qirIUbAIduKrPvfI0bAKAI>.

Google Earth. Parque Estadual do Sítio Rangedor. < https://earth.google.com/web/search/Parque+Estadual+do+S\%c3\%adtio+do+Rangedor++B\%c3\%bazios,+S\%c3\%a3o+Lu\%c3\%ads+-+MA/@-2.4980867,-44.2680355,31.24484023a,1055.41801 936d,35y,0h,45t,0r/data=CqsBGoABEnoKJ DB4N 2Y2OGRjMjM5ZmNkYzFkOjB4ZmFjM2Y2MDU1M2Y2Y2UyNxmclDjhFPwDwCFgVb38TiJGwCpAUGFycXVIIEVzdGFkdWFsIGRvIFPDrXRpbyBkby BSYW5nZWRvciAtIELDunppb3MsIFPDo28gTHXDrXMgLSBNQRgCIAEiJgokCd2rt1WjXTNAEd2rt1WjXTPAGS_pVYiwGEIAISzpVYiwGEnAKAI >.

Google Earth. Reserva do Batatã. < https://earth.google.com/web/search/Reserva+do+Batat\%c3\%a3+/@-2.5983306,-44.2688892,9.14886068a, 1055.3260015d,35y,0h,45t,0r/data=Cn0aUxJNCiQweDdmNjg0ZTBkMGE4YmI2MToweGJhNjM3NGMzNDliMWM2MzgZhpG5jWHJBMAhsR8Y9moiRs AqE1Jlc2VydmEgZG8gQmF0YXTDoyAYAiABIiYKJAnsIO_9TzkEwBGCCqcAMkYEwBkwlABcnBtGwCE4FQZPXx1GwCgC>.

Google Earth. Reserva do Itapiracó. < https://earth.google.com/web/search/Reserva+do+Itapirac\%c3\%b3+-+Turu,+S\%c3\%a3o+Lu\%c3\%ads+-+MA/@ . 2.53112985,-44.22259015,53.77176022a,1055.38808726d,35y,0h,0t,0r/data=CigiJgokCY_1OfTv5APAEd4HgXxrBwTAGXrUSFaKIUbAIT9sZ7fYI0bA>.

Google Maps. Avenida dos Holandeses. <https://www.google.com.br/maps/place/Av.+dos+Holandeses+-+MA. 2020>.

Google Maps. Avenida General Artur Carvalho. < https://www.google.com.br/maps/place/Av+Gen+Artur+Carvalho+Turu+--Turu>.

Google Maps. Avenida Jerônimo de Albuquerque. 〈https://www.google.com.br/maps/place/Av.+Jeronimo+de+Albuquerque+-+Recanto +Vinhais> .

Google Maps. Ponte que interliga Parque dos Nobres à cidade. 〈https://www.google.com.br/maps/place/Parque+dos+Nobres〉 .

Google Maps. Terminais de Integração em São Luís. < https://www.google.com.br/maps/search/terminais+de+integra\%C3\%A7\%C $3 \% \mathrm{~A} 3 \mathrm{o},+\mathrm{S} \% \mathrm{C} 3 \% \mathrm{~A} 3 \mathrm{O}+\mathrm{Lu} \% \mathrm{C} 3 \% \mathrm{ADs}+-+\mathrm{MA} />$.

Governo Do Estado Do Maranhão. Ponte Pai Inácio melhora condições de trânsito para mais de 300 mil moradores da Grande São Luís. <https://www.ma.gov.br/agenciadenoticias/?p=136103〉.

Guimarães, P. B. V., \& de Alencar Xavier, Y. M. (2016). Smart cities e direito: conceitos e parâmetros de investigação da governança urbana contemporânea. Revista de Direito da Cidade, 8(4), 1362-1380.

Hales, M., Peña, A. M., Peterson, E., Dessibourg- Freer, N (2018). Global Cities Index 2018-GCI. A T kearney. <https://www.atkearney.com/globalcities/2018>.

Hall, R. E., Bowerman, B., Braverman, J., Taylor, J., Todosow, H., \& Von Wimmersperg, U. (2000). The vision of a smart city. Brookhaven National Lab., Upton, NY (US).

Harrison, C., Eckman, B., Hamilton, R., Hartswick, P., Kalagnanam, J., Paraszczak, J., \& Williams, P. (2010). Foundations for smarter cities. IBM Journal of research and development, 54(4), 1-16.

Höjer, M., \& Wangel, J. (2015). Smart sustainable cities: definition and challenges. In ICT innovations for sustainability (pp. 333-349). Springer, Cham.

Instituto Brasileiro de Geografia e Estatística (IBGE). Censo 2010. <https://censo2010.ibge.gov.br/sinopse/index.php?dados=8>.

International Project Management Association (IPMA). $1^{\circ}$ Smart Cities Symposium. < https://www.ipma.world/>.

International Telecommunication Union (ITU) (2015). Focus Group on Smart Sustainable Cities FG-SSC. <https://www.itu.int/en/ITUT/focusgroups/ssc/Pages/default.aspx $>$. 
Jornal Pequeno (2017). São Luís tem a segunda menor malha cicloviária do país. Jornal Pequeno e G1. 〈https://jornalpequeno.com.br/2017/02/19/sao-luistem-segunda-menor-malha-cicloviaria-do-pais/>.

Kobayashi, A. R., Kniess, C., Serra, F. A., Ferraz, R. R. N., \& Ruiz, M. (2017). Cidades Inteligentes e Sustentáveis: Estudo Bibliométrico e de Informações Patentárias (Smart Sustainable Cities: Bibliometric Study and Patent Information). International Journal of Innovation, 5(1), 77-96.

Komninos, N. (2006). The architecture of intelligent cities. Intelligent Environments, 6: 13-20.

Komninos, N. (2008). Intelligent Cities and Globalisation of Innovation. Routledge.

Komninos, N. (2015). The age of inteligente cities: Smart environments and innovation-for-all strategies. Routledge.

Lazaretti, B. (2012). "Como funciona a coleta de lixo em Barcelona?" < https://super.abril.com.br/mundo-estranho/como-funciona-a-coleta-de-lixo-embarcelona/>.

Leydesdorff, L., \& Deakin, M. (2011). The triple-helix model of smart cities: A neo-evolutionary perspective. Journal of urban technology, 18(2), 53-63.

Maranhão. Governo estabelece regionalização com a inauguração de hospitais macrorregionais. Agência de Notícias. <https://www.ma.gov.br/governoestabelece-regionalizacao-com-inauguracao-de-hospitais-macrorregionais/>.

Maranhão. Obras de habitação e urbanismo do Governo do Maranhão avançam em São Luís. Agência de Notícias. <http://www.ma.gov.br/agenciadenoticias/desenvolvimento/obras-de-habitacao-e-urbanismo-do-governo-do-maranhao-avancam-em-sao-luis>.

Martins, M. F., Salles, M. C. T., de Macedo, E. T., Nunes, E. R., \& Ribeiro, R. O. (2020). Problemas urbanos que interferem na sustentabilidade de cidades: um estudo no Município de Serra Redonda-Paraíba-Brasil. Research, Society and Development, 9(8), e730986177-e730986177. MERCER (2018). Quality of Living City Ranking 2018 - QLCR. Mercer. <https://www.mercer.com/newsroom/2018-quality-of-living-survey.html>.

Nam, T., \& Pardo, T. A. (2011). Conceitualizando cidade inteligente com dimensões de tecnologia, pessoas e instituições. In Proceedings of the $12^{a}$ conferência anual de pesquisa governamental digital: inovação governamental digital em tempos desafiadores (pp. 282-291).

Nóbrega Jr (2018). Nova York e Curitiba-Cidades Mais inteligentes do mundo. <http://floripamanha.org/2018/05/nova-york-e-curitiba-cidades-maisinteligentes-do-mundo/>.

Plano Estadual de Saúde/MA (PES) (2016). PES 2016-2019. < https://www.conass.org.br/pdf/planos-estaduais-desaude/MA_Plano\%20de\%20saude\%202016-2019.pdf>.

Prefeitura de São Luís, MACROPLAN (2013). Implantação da gestão estratégica orientada para resultados na prefeitura de São Luís. 〈https://www.saoluis.ma.gov.br/midias/anexos/1734_estrategia_de_longo_prazo_2033_-_produto_2_produto_3_e_produto_4-compressed.pdf>.

Santos, L (2017). Situação das escolas da rede municipal de São Luís é crítica. O Estado. < https://imirante.com/oestadoma/noticias/2017/04/22/situacao-dasescolas-da-rede-municipal-de-sao-luis-e-critica/>.

Silva, E. L., Menezes, E. M (2005). Metodologia da pesquisa e elaboração de dissertação (4a ed). UFSC.

Sousa, A., Rodrigues, D., Diniz, F., Oliveira, F (2019). Modo precário e segregado de moradia: um olhar sobre o cortiço em São Luís - MA. eMetropolis, 36. <http://emetropolis.net/system/artigos/arquivo_pdfs/000/000/284/original/emetropolis36_ensaio.pdf?1551137084>.

TECMUNDO (2013). Pontos de ônibus "High Tech" são instalados na Avenida Paulista. < https://www.tecmundo.com.br/transito/48463-pontos-de-onibushigh-tech-sao-instalados-na-avenida-paulista.htm>.

THE ECONOMIST GROUP (2018). The Economist Intelligence Unit. Global Liveability Index $2018 \quad-\quad$ GLI. <https://www.eiu.com/public/topical_report.aspx?campaignid=Liveability2018>.

Urban Systems (2018). Ranking Connected Smart Cities 2018. Ed Urban Systems, 2: 1-69.

Vale, P. S (2018). São Luís e o mito da falta de planejamento urbano. Caos planejado. <https://caosplanejado.com/sao-luis-mito-falta-planejamento-urbano/>.

Weiss, M. C., Bernardes, R. C., \& Consoni, F. L. (2013b). Cidades inteligentes: a aplicação das tecnologias de informação e comunicação para a gestão de centros urbanos. Revista Tecnologia e Sociedade, 9(18).

Weiss, M. C., Bernardes, R. C., Consoni, F. L (2013a). Cidades inteligentes: casos perspectivos para as cidades. $\langle$ http://www.redbcm.com.br/arquivos/bibliografia/cidades_inteligentes-_casos_e_perspectivas_para_as_cidades.pdf $>$.

Yamato, N., Hamada, Y., Matsuda, M., et al (2019). Global Power City Index-GPCI. 2018. Institute for Urban Strategies, The Mori Memorial Fundation. <http://mori-m-foundation.or.jp/pdf/GPCI2018_summary.pdf>.

Yeandle, M., \& Wardle, M (2019). The Global Financial Centers Index- GFCI. Long Finance \& Global Financial Centres. Z/Yen in Partnership \& CDI. $<$ https://www.longfinance.net/programmes/financial-centre-futures/global-financial-centres-index/>. 